\title{
SYNTACTIC CASE AND DP (IN)VISIBILITY
}

\author{
Gabriela Alboiu*
}

\begin{abstract}
This article argues for a dependency between structural Case and phasal domains and against Case values as intrinsic properties of $(\mathrm{C})-\mathrm{T}$ and $\left(\mathrm{v}^{*}\right)-\mathrm{V}$. Rather, Nominative or Accusative values are derived compositionally from properties of the entire Probing domain: (i) NOM occurs whenever the Probing domain is specified as $[\mathrm{uD}, \mathrm{u} \phi / \pi]$, while (ii) Acc is assigned if the Probing domain is specified as $[\mathrm{uD}]$. The presence of a [uCase] feature is assumed on all DP arguments, whether null or overt. However, after Case valuation, DPs with inherent intensions and extensions will be lexicalized but variables, such as PRO, will not. The analysis focuses on DP subjects (both lexical and PRO) in non-finite CPs, and relies on availability of null expletive pro as a UG primitive. It assumes Chomsky's Feature Inheritance Model (Chomsky 2007, 2008, Richards 2007), default Case as in Schütze (1997, 2001), as well as Distributed Morphology (Halle and Marantz 1993, Embick 2007). It aligns with views where the Case Filter, while syntactically relevant (Legate 2008), is a PF constraint (Lasnik 2008, Sigurðsson 2008).
\end{abstract}

Keywords: Case, phases, agreement, expletive pro, PRO, non-finite CPs, lexical subjects

\section{Introduction}

The paper explores Case licensing and valuation under assumptions that correlate all A-features to the presence of a phase head (Chomsky 2007, 2008 et seq.). Specific questions, such as to what extent is Case still a property of the computational system, what the role of agreement, understood as $\phi$-specifications, would now be, or whether NOM and ACC feature-specifications are properties of $\mathrm{T}$ and $\mathrm{v}^{*}$, respectively, are now paramount.

In engaging with such questions, a distinction must be made between DP arguments and other types of nominals (e.g. predicates, adverbials, dislocated phrases). DP arguments have special status in that they are visible to A-relationships, a property of the computational system. Consequently, I assume that DPs associated with a theta-role have a [uCase] formal feature which is active until Spell-Out. If [uCase] is checked at first Merge, thus involving a theta-role relationship, the appropriate inherent Case (Chomsky 1986) value ensues (e.g. DAT, GEN, ACC) upon Transfer. If not checked upon first Merge, I propose that [uCase] valuation depends on the feature composition of the domain that A-Probes it. If [uCase] is never A-Probed for, I assume it checks upon Transfer without valuation. This is a direct consequence of the initial view where the Case Filter is a PF rather than an LF interface requirement (Chomsky 1980, Lasnik 2008, and Sigurðsson 2008). Without a Case value, lexicalization of necessity fails, triggering ungrammaticality, unless the DP argument is inherently silent (e.g. PRO). Crucially, a violation of the Case Filter bleeds lexicalization, while failure to lexicalize is independent of Case.

The following general conclusions emerge. First, I argue that structural Case, now incumbent on the phase head rather than on the presence of phi-features/agreement

\footnotetext{
*York University, Department of Languages, Literatures and Linguistics, galboiu@yorku.ca.

Bucharest Working Papers in Linguistics XXI, 1, 7-49, e-ISSN 2392-8093, ISSN-L 2069-9239 DOI: 10.31178/BWPL.21.1.1
} 
properties, is not insensitive to $\phi$-specifications. Related to this, $\mathrm{T}$ and $\mathrm{v}^{*}$ do not have intrinsic NOM and ACC features, respectively. Rather, these values reflect properties of the Probing domain, with $[\pi]$ being the crucial distinguishing ingredient, paramount for NOM. Second, the overt versus null status of arguments has no bearing on Case checking and valuation as syntax is not privy to phonetic features. Lastly, I assume that lexicalized DP arguments never bear instances of default Case. If that were possible, the Case Filter would be vacuous (see also Schütze 1997, 2001). Non-argument DPs, on the other hand, lack Case features and their corresponding values. Given that PF has to insert a vocabulary item, the language specific default Case form will be used (à la Schütze 2001). To sum up, Case is still syntactically relevant for DP arguments (see also Legate 2008), with the added comment that "syntactic relevance" is reconfigured as engaging in an A-relationship, rather than specific Case values in $\mathrm{T}$ or $\mathrm{v}^{*}$. Non-argument DPs, however, engage with Case exclusively at the PF level. Syntax then "has no case features" (Sigurðsson 2008, 2009), such as NOM or ACC, but A-relations in syntax enable specific Case values. ${ }^{1}$

Let me briefly elaborate on each relevant point and thus give the reader some preliminary insight into the reasoning above.

It has been standard in generative grammar since the seminal work of George and Kornfilt (1981) and Chomsky (1981, et seq.), to correlate structural Case with agreement. However, cross-linguistic data makes such a claim empirically difficult to maintain. First, there are languages with NOM and ACC lexical (overt) subjects in domains lacking phispecifications. ${ }^{2}$ Furthermore, there is variation as to whether these subjects lexicalize as NOM or ACC. Consider the data in (1) showing a NOM subject in a Romanian gerund adjunct (1a) ${ }^{3}$, and an ACC subject in a Latin infinitival subject clause (1b):
(1) a. [cP Fiind noi gata $\mathrm{cu}$ toții], am pornit la drum. [ being.GER we.NOM ready with all] have-1PL started at way ${ }^{4}$ 'Given that we were all ready, we started on our way.'

(Romanian)

\footnotetext{
${ }^{1}$ A line of reasoning that is hugely indebted to the work of Marantz (1991/2000) and followers (e.g. Harley 1995, Schütze 1997, 2001).

${ }^{2}$ I use the term "subject" to refer to the structurally highest DP argument within the predicational domain that is "active" (i.e. can act as a Goal with [uCase]).

${ }^{3}$ While in Romanian clausal gerunds like (1a) cannot occur in argument positions, these are not labelled participles as the language has distinct morphology for both categories.

${ }^{4}[\mathrm{uF}]$ is used to represent uninterpretable formal features. Checked features are striked and traces are indicated via angled brackets. The following abbreviations and symbols are used: $\mathrm{ABL}=\mathrm{Ablative}, \mathrm{ABS}=\mathrm{Absolutive}$, $\mathrm{ACC}=$ Accusative, $\mathrm{Agr}=$ agreement, $\mathrm{AOR}=$ aorist, $\mathrm{ASP}=$ aspect, $\mathrm{AUX}=$ auxiliary, $\mathrm{CL}=$ object pronominal clitic, $\mathrm{COP}=$ copula, $\mathrm{DAT}=$ Dative, $\mathrm{DES}=$ desiderative, $\mathrm{DFT}=$ default, $\mathrm{ERG}=$ Ergative, $\mathrm{F}=$ feminine, $\mathrm{FUT}=$ future, $\mathrm{g}=$ gender, GEN $=$ Genitive, GER $=$ gerund, SBJ: subjunctive, $\mathrm{IMP}=$ imperative, $\mathrm{INF}=$ infinitive, $\mathrm{INSTR}=$ Instrumental, $\mathrm{LOG}=$ logophoric, $\mathrm{M}=$ masculine, $\mathrm{N}=$ neuter, $\mathrm{NOM}=$ Nominative, $\mathrm{OBJ}=$ object, $\mathrm{OP}=$ operator, PRES $=$ present, $\mathrm{PRF}=$ perfect, $\mathrm{PL}=$ plural, $\mathrm{POSS}=$ possessor, $\mathrm{PRTC}=$ participle, $\mathrm{PST}=$ past, $\mathrm{REFL}=$ reflexive, $\mathrm{SCL}=$ subject pronominal clitic, $\mathrm{SU}=$ subject, $\mathrm{SG}=$ singular, $\pi=$ person, $\#=$ number, and $\mathrm{PE}=$ a preposition associated with Romanian direct objects that have an $<\mathrm{e}>$ type denotation (see Cornilescu 2000a).
} 

b. Me interest [CP te studere]. me.ABL it is good [ you.ACC study] 'It is to my advantage that you study.'

Further complications arise once we consider languages where Case valuation in non-finite contexts is determined by linearization properties, with post-verbal subjects strictly NOM, as discussed by Mensching (2000: 20) for Old Italian and shown in (2):
a. $\quad \mathrm{Tu}$ non ti rallegri [CP aver io incontrata una morte] you not CL delight [ to-have $\mathbf{I}$ found a death] 'You are not glad that I have found death.'
(Old Italian, D'Azeglio, ch. 18, p. 222, in Schwendener 1923:72)
b. Negar non voglio esser possibile, [CP lui essere beato.. deny-INF not want be-INF possible [ him be-INF blessed 'I do not want to deny that it is possible that he is blessed.'
(Old Italian, Boccaccio, Dec., I, 1; cf. Schwendener 1923:82) ${ }^{5}$

Clearly, it is not possible to assume that both values in (2) are instances of some default. Linguistic patterns invite consistent formalization and principled accounts.

Furthermore, variation is not restricted to lexical subjects and the T domain. For example, West Country varieties of English, show both NOM and ACC values on direct objects. Consider (3) from Newfoundland English (Ruth King, personal communication):

(3) a. She pushed me / I down.

b. Pass him / he over to me.

It is useful to point out that these dialects of English have null expletives (Ihalainen 1991), a property shared with languages capable of lexicalizing NOM subjects in nonfinite domains.

I argue that this relationship is not accidental, the conceptual claim being that expletive pro is a parametrized UG primitive with a role in Case valuation. In particular, the null expletive, as an uninterpretable phi-feature bundle containing a person $(\pi)$ deficiency, probes an active DP and guarantees a NOM value on this Goal/associate.

To sum up, "Case values" are equivalent to engaging in an A-relationship, such that a DP argument has the following Case values: (i) a NOM value, if and only if the Probing domain is specified as $[\mathrm{uD}, \mathrm{u} \phi]$, where $[\mathrm{uD}]$ is equivalent to T's EPP; (ii) an ACC value, if the Probing domain is specified as $[\mathrm{uD}]$; (iii) an inherent value assigned at first Merge; (iv) no value, if no Probing domain, hence no A-chain. In this last scenario, the DP fails to lexicalize.

\footnotetext{
${ }^{5}$ To avoid any confusion given that in Old Italian lui was also sometimes used for the NOM (e.g. in Dante's work), Mensching (2000: 208) points out in fn. 6 that Boccaccio strictly distinguishes between lui/lei (ACC) and egli/ella (NOM) in the Decameron.
} 
(4) provides schemas of how this works. For ease of exposition, I represent thetaroles as category features (Hornstein 1999, Manzini and Roussou 2000, Adger 2003, a.o.). Dotted arrows indicate feature-inheritance, full arrows indicate an A-relationship (either triggering a first Merge or a Probe-Goal environment). Only relevant A-features are shown.

(4) i. Inherent Case (e.g. Dative): theta-role comes equipped with Case value

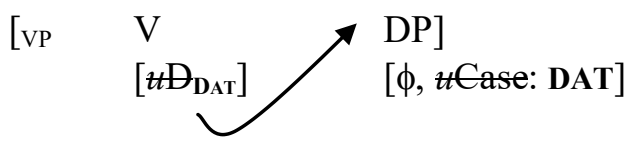

ii. Structural ACC Case:

(a) on objects

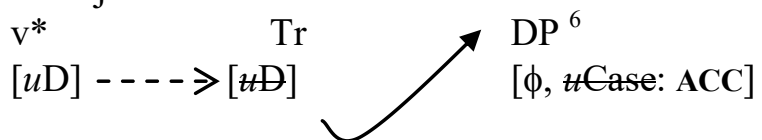

(b) on subjects in phi-feature-less CPs (e.g. non-finite clauses)

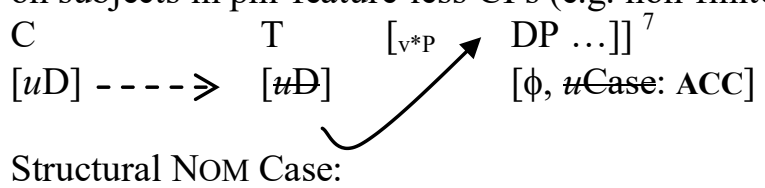

iii. Structural Nom Case:

(a) on subjects in finite $\mathrm{CPs}$

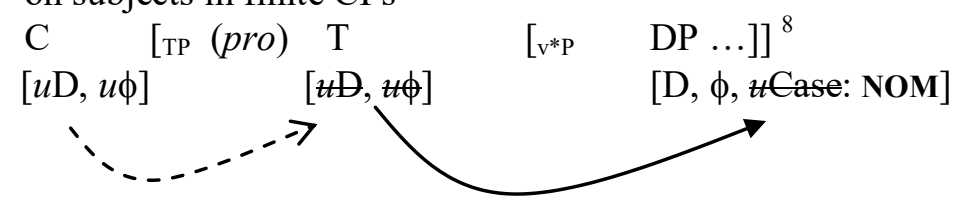

(b) on subjects in non-finite CPs (with expletive pro)

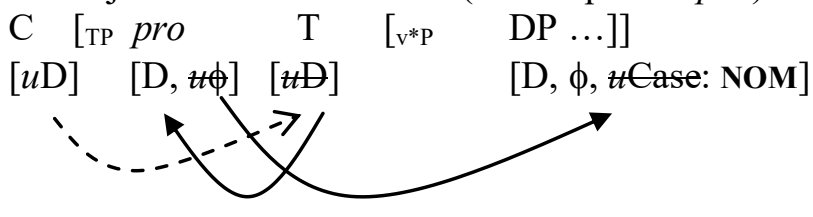

\footnotetext{
${ }^{6}$ Nothing hinges on the exact label of the verbal head assigning Case to a VP internal DP; this can be v, the verbalizing head of Marantz (2001), $\mathrm{T}_{\mathrm{o}}$ of Pesetsky and Torrego (2004a), Tr of Bowers (2002), AGR-O of Lasnik (2003), or V of Chomsky $(2007,2008)$. Crucially, it is a verbal head involved in the stacking of events which is lower than the theta-assigning head responsible for the insertion of subjects, otherwise labelled Voice in Marantz (following Kratzer, 1996), v in Pesetsky and Torrego (following much of Chomsky's work who in turn follows Marantz), Pr(ed) in Bowers, and $v^{*}$ in Chomsky $(2007,2008)$ to distinguish it from unaccusative v. Following Bowers (2002), in this paper I use Tr for the complement of $\mathrm{v}^{*}$ and take this to be a functional head. See Pesetsky and Torrego (2006) for reasons as to why only functional heads may act as Probes and establish Agree.

${ }^{7} \mathrm{I}$ show $\mathrm{T}$ as the proxy head for $\mathrm{C}$, as standardly assumed. However, it is unlikely that $\mathrm{T}$ is always involved. Specifically, Romanian gerunds (Avram 2003) and infinitives in Ancient Greek (Sevdali 2005) have been argued to have aspectual, rather than temporal properties, so in those cases $\mathrm{C}$ presumably discharges its A-properties on Asp, rather than T (see Section 2).

${ }^{8}$ For derivations with expletive pro checking EPP $([\mathrm{uD}]$ on $\mathrm{T})$ in Spec,TP, the DP Goal is phi-Probed twice: once by the expletive, once by T. Either way, NOM is expected.
} 
(c) on objects (with expletive pro)

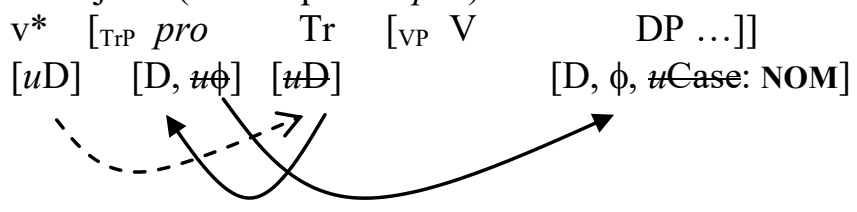

For Ergative-Absolutive languages, following Legate (2008) and Woolford (1997), I treat Ergative as an instance of inherent Case, and Absolutive as equivalent to structural NOM (see also Bittner and Hale 1996). (5) is representative of ABS = NOM.

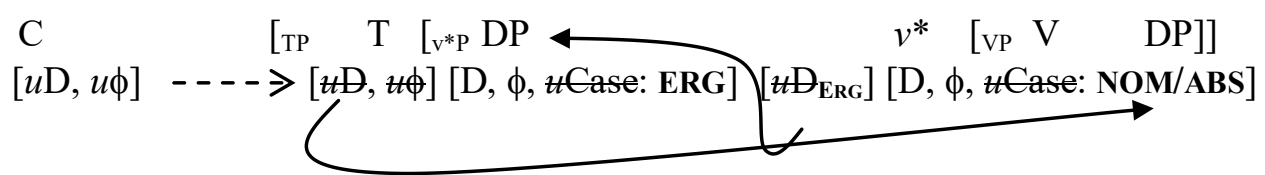

Where does that leave PRO then? As an argument, it must bear [uCase]. The logic that PRO checks either null Case (Chomsky and Lasnik 1995) or is an instance of default (e.g. Boeckx and Hornstein 2006, for Icelandic) is difficult to maintain, both conceptually and empirically once we agree that non-finite CP domains can value structural NOM or ACC. In addition, various literature argues for PRO bearing either structural or quirky/inherent Case (e.g. Adger 2007, Bobaljik and Landau 2009, Cecchetto and Oniga 2004, Landau 2008, 2013, Schütze 1997, Sigurðsson 1991, 2008, a.o.). Section 5 details an analysis of how PRO checks Case.

The paper assumes Chomsky's Feature Inheritance Model (Chomsky 2007, 2008, Miyagawa 2010, 2017, Richards 2007), as well as Distributed Morphology (Halle and Marantz 1993, Embick and Noyer 2007), and is organized as follows. Section 1 focuses on the role of the phase head in linguistic computations, the limitations of equating Case with agreement, and the relevance of a phi-complete Probe in Case valuation. Section 2 discusses the relationship between Tense, as a property of the CP phase domain, and Case values. Section 3 revisits the logic against default Case on lexical DP arguments and introduces novel proposals for Case valuation. Section 4 focuses on non-finite CP domains which are shown to be phi-incomplete. It proposes that null expletives, as $\phi$-Probes, affect the encoding of Case. It offers a systematic account of Case values on lexical subjects in non-finite domains by examining Romanian, a null expletive language, and English, which lacks this syntactic primitive. It concludes with languages showing inconsistent Case lexicalization in non-finite CP domains. Section 5 focuses on PRO. I argue that failure to lexicalize is independent of Case and propose an analysis whereby PRO is cross-linguistically valued with structural NOM if A-Probed. Section 6 highlights predictions the analysis makes beyond non-finite CPs and in section 7 I offer a brief discussion of general implications for Case theory. Section 8 is a conclusion. 


\section{Phi-features (agreement) and structural Case}

Chomsky $(2007,2008)$ redefines the relationship between C, as a phase head (or Edge), and T, as its complement. Specifically, $\mathrm{T}$ inherits its features from $\mathrm{C}$ so that it only operates as a Probe derivatively. There is no [uCase] Probe, and [u $\phi]$ acts as a Case Probe instead.

The question is whether every phase head possesses a complete set of A-related features, specifically, EPP/[uD] and [u $\phi]$, or whether this varies with properties of each phase head. This paper argues for agreement (defined as $[u \phi]$ ) as a strict property of finite $\mathrm{C}$ heads but for the EPP (construed as a structural requirement coerced by CI interface conditions - Chomsky 2007) as a uniform property of all phasal heads. This proposed dichotomy raises questions with respect to the standard view whereby structural Case is incumbent on agreement. Typically, $\phi$-complete $\mathrm{T}$ Probes are seen as synonymous to lexical subjects with NOM Case, and $\phi$-complete $v^{*}$ Probes are taken to be synonymous to DP objects valued ACC (though see Baker 2015). ${ }^{9}$

There are, however, various conceptual and empirical problems with a strict correlation of Case with $\phi$-features. First, the idea that (C)-T ensures NOM Case, while $\mathrm{v}^{*}-\mathrm{V}$ ensures ACC Case, if correct, is theoretically unwieldy. If all A-related features are uninterpretable on the various phase heads and, implicitly, their complements, then how can they a priori have values, such as NOM and ACC? Second, it is unclear what properties of $\mathrm{T}$ and $\mathrm{v}^{*}$ would license this split (Sigurðsson 2009) or why $\phi$-completeness matters (Carstens 2001, Pestesky and Torrego, 2004b). Carstens (2001: 148) observes that "gender is systematically excluded from the features of subject agreement in Indo-European languages with gender systems," so such T is $\phi$-incomplete. Third, given the lack of $\phi$-feature agreement between $\mathrm{v}^{*}$ and the DP it Case-marks, there is no evidence that $\mathrm{v}^{*}$ has $[\mathrm{u} \phi]$ (see also Baker et al. 2005). ${ }^{10}$

The two subsections below sharpen the exact relationship between structural Case and $\phi$-properties, by presenting empirical data arguing against $\phi$-Probes as a prerequisite for structural Case and outlining a preliminary proposal for Case valuation.

\footnotetext{
9 Aside from Chomsky's work, for recent proposals on the relationship between Case and agreement, see Baker 2008, Landau 2004, Legate 2008, Markman 2009, and Schütze 1997, 2001.

${ }_{10}$ Note that "agreement" is used here to refer strictly to phi-feature agreement and not cases of object agreement that reflect on the definiteness of the DP object (e.g. Hungarian - Bartos 1997, Coppock 2004, Farkas p.c., Chichewa and Bantu more generally - Baker 2008, Slave - Rice 1989, Ndebele - Alboiu and Avery 2009). For instances, in Hungarian, transitive verbs with definite/specific objects use a paradigm that is distinct from that used for transitive verbs with indefinite objects and intransitives; however, agreement is not with person and number (references cited above). I also discount head-marking languages of the Bantu and Iroquoian type, where object DPs are adjuncts rather than arguments (Baker 1996, Markman 2009), as it is unclear whether these bear structural Case (these are not morphologically Case marked). Incidentally, note that in some of these languages it is unlikely that the object marker denotes an instance of agreement. Kramer (2010) points out that PP arguments can be referenced by the object marker in Amharic, regardless of whether ACC Case is at stake, while Woolford (2003) argues that PPs do not participate in agreement.
} 


\subsection{Against $[u \phi]$ as a Case prerequisite: Evidence from non-finite CPs}

Traditionally, the distinction between finiteness and non-finiteness is correlated to the presence versus absence of inflectional morphology associated with T (e.g. Binnick 1991, Ledgeway 1998 and references therein). ${ }^{11}$ While this correlation is not immediately straightforward (Alboiu 2006, Hill and Alboiu 2016, a.o.), intuitively, CPs without inflectional morphology on $\mathrm{T}$, in languages with otherwise inflected $\mathrm{T}$ paradigms, are arguably $\phi$-featureless (see Alboiu 2006, Bianchi 2008, Landau 2004, Roussou 2006). This claim is supported by various empirical data below.

For instance, subject clitics are illicit in non-finite CPs, even where NOM subjects are permitted. Poletto (2000) notes that in Friulian, a Northern Italian dialect, subject clitic doubling is extremely common. However, (6a) shows that subject clitics are ruled out in gerunds, despite the presence of a postverbal NoM lexical subject. French data makes a similar point: while non-clitic DP subjects are legitimate in gerunds, subject clitics are not; (6b) is based on Reed (2011).

a.

(*E) Vint Marie/ je ciacaraat cun ti, e ha SCL having Marie/she spoken with you, SCL have diciduut di cumprà el livri. decided of buy.INF the book 'Having spoken with you, Mary decided to buy the book.'

(Paoli, p.c.)

b. Les villageois $/ *$ Ils $/ *$ Eux étant pauvres, ils n' avaient pas the villagers / they/ them being poor, they NEG had NEG les moyens d' engager un expert. the means of hire-INF an expert 'The villagers $/ *$ They $/ *$ Them being poor, they didn't have the financial resources needed to hire an expert.'

Following Roberts (2010), subject clitics in Northern Italian/Tuscan dialects are [u $\phi]$ bundles derived from $\mathrm{C}$. Lack of a subject clitic in $(6 a, b)$ shows $[u \phi]$ to be absent in non-finite CPs.

Linearization of pronominal clitics in Romanian points to a similar conclusion. Săvescu-Ciucivara (2007) argues that Romanian clitic ordering is sensitive to Person $(\pi 1>\pi 2)$ and Case ranking (DAT $>$ ACC), but that $\pi$ ranking restrictions disappear in non-finite contexts; see (7):

\footnotetext{
${ }^{11}$ Note that under this division of labour, inflected infinitives in European Portuguese of the type in (i) from Raposo (1987: 86) would qualify as 'finite'.

(i) Será difícil [eles aprovarem a proposta].

'It will be difficult they to-approve-AGR the proposal.'

However, this is not why I do not discuss this particular construction here. Terminology aside, the Nominative subject in (i), a proposta 'the proposal', could be licensed by either agreement, the phase head, or both. See both Raposo (1987) and Ambar (2006) for evidence that these inflected infinitives are CP phasal domains.
} 
(7)
a. * Tुi m- a prezentat Ion la petrecere.
CL.2SG.DAT CL.1SG.ACC has introduced Ion at party
'Ion has introduced you to me to the part.'
b. Dîndu- ţi- mă de nevastă, tata a giving.GER CL.2SG.DAT CL.1SG.ACC of wife father has câştigat mulţi bani.
gained much money
'Giving me to you in marriage, my father has gained a lot of money.'

Having shown that there is no $\phi$-feature transmission from $\mathrm{C}$ to its proxy head in uninflected domains, the task is to account for the empirical observations discussed below.

\subsection{Case-valued subjects in non-finite CPs}

Cross-linguistically, there are various instances of lexical subjects in non-finite (uninflected) CP domains, with variation for NOM or ACC values, at both a macro- and a micro-parametric level. These are strictly NOM in at least infinitives and gerunds in most Ibero-Romance, Greek gerunds (Sitaridou 2002), West Flemish infinitives (Haegeman 1985), absolute participial constructions in Hungarian (Liptak, p.c.), Albanian (Kallulli, p.c.), Italian Aux-to-Comp (Rizzi 1982, Belletti 1990), and Czech conditional infinitives (Tomić, p.c), as the data in (8) show: ${ }^{12}$
a. Î punea la calculator [CP pentru a avea
CL.3PL.M.ACC put.3SG at computer [CP for INF have
tu / *tine linişte]
2.SG.NOM-*ACC quiet]

'She would leave them at the computer for you to have peace and quiet.'

b. [CP Fiind noi gata $\mathrm{cu}$ toţii], am pornit la drum.

[ being.GER we.NOM ready with all] have-PL started at way

'Given that we were all ready, we started on our way.'

c. [CP Odată (fata / ea) deşteptată (fata / ea)],

[cP once girl-the.NOM/she awoken-SG.F girl-the.NOM/she]

mama puse de mîncare.

mother-the put.PAST.3SG of food

'The girl having awoken, mother started preparing some food.'

(Romanian)

\footnotetext{
${ }^{12}$ Various authors assume $\mathrm{P}$ to be external to $\mathrm{CP}$ but to have a role in activating Case-assigning properties of the infinitive Inflectional domain, properties intrinsically related to agreement (e.g. Haegeman 1985, Ledgeway 1998, Motapanyane 1995, Raposo 1989). This is untenable under the current approach which assumes no $[\mathrm{u} \phi]$ on $\mathrm{T}$ in these CPs (see also Schütze 1997).
} 
d.

$\begin{array}{lllll}\text { Lo supimos } & \text { [CP después } & \text { de } & \text { llegar } & \text { él }] . \\ \text { we found out } & {[\text { CP after }} & \text { of } & \text { arrive.INF } & \text { he.NOM }]\end{array}$

'We found out after he had arrived.'

(Spanish, Ledgeway 1998: 5)

e. [cP Avendo Gianni / (lei) chiuso il dibattito], la riunione

[CP having Gianni/(3SG.F.NOM) closed the debate] the meeting

è finite prima.

is finished before

'Gianni (Her) having closed the debate, the meeting ended early.'

(Italian, adapted from Belletti 1990: 98)

f. [CP Udělat to moje sestra], nic by se

[ do-INF that my sister.NOM] nothing would REFL

nestalo,

not happen.N.SG.PRTC

(ale protože jsem to udělala já, matka se zlobí).

but because it was done by me, mother is annoyed

'If it was done by my sister, everything would be okay (but because it was done by me, mother is annoyed).'

g. [CP Meeik da te zeggen], hee-se dat hus gekocht.

[CP withI.NOM that to say] has-she that house bought

'Because of my saying that she has bought that house.'

(West Flemish, Haegeman 1985: 125)

h. [CP A gyermek felébredvén], az anya ebédet készített.

[CP the child.NOM wake.PRTC] the mother lunch.ACC made.3SG

'The child having woken up, the mother prepared lunch.'

(Hungarian, Liptak, p.c.)

These non-finite domains are adjuncts, so strong islands (in the sense of Cinque 1990) or phases, which I take to be the crucial ingredient to Case checking (see also Alboiu 2006, Branigan 2005, Chomsky 2007, 2008, Sitaridou 2002). In tensed ("personal", following Ledgeway 1998) infinitive clause adjuncts (8a, d, f, g), gerund adjuncts ( $8 \mathrm{~b}, \mathrm{e})$ and absolute participial constructions $(8 \mathrm{c}, \mathrm{h})$, lexical NOM subjects are licit in the absence of $[\mathrm{u} \phi]$ on $\mathrm{T}^{13}$

However, the lexical subject in non-finite subject or adjunct domains can also be valued ACC. This is the case for English infinitive and gerund clauses, infinitives in Irish (McCloskey 1985), Latin (Wyngaerd 1994), and Ancient Greek (Sevdali 2005, 2007); see data in (9):

\footnotetext{
${ }^{13}$ Absolute participial constructions typically show agreement in gender and number in Romance, on a par with participles in passives. Following Chomsky (2008), inflection on participles is simply an effect of agreement, with no significance in the syntactic computation. Consequently, $\phi$-features (crucially, $\pi$ ) on (C)-T are not present; see also discussion for (6b).
} 
(9) a. [CP For him to listen to that talk] was awkward.
b. [CP Him baking the pie] pleased everyone.
c. Fe:mi [CP se men egno:kenai peri touto:n]
say-I you-ACC to know-PRF about these-GEN]
[CP eme de suneire:kenai tais sais epithumiais]
[ me-ACC to go along-PRF the your wishes-DAT]
'I say that since you knew about these things, I went along with your wishes.'

(Greek, Isokrates, Ad Philippum III, 3:3-4. In Sevdali 2005: 134)
d. Cánathaobh í a bheith chomh deacair?
why it.ACC be.INF so difficult
'Why should it be so difficult?'
e. Me interest [CP te studere].
me.ABL it is good [ you.ACC study]
'It is to my advantage that you study.'

(Irish, McCloskey 1985: 194)

(Latin, Wyngaerd 1994: 124)

Lastly, there are instances of lexical subjects where Case valuation in non-finite contexts is sensitive to word order, such that postverbal subjects are strictly NOM. See the infinitive data from Old Italian in (2), from Mensching (2000: 20), repeated as (10), and the gerund data from Latin in (11). Typically, Latin gerunds appear with ACC subjects (Mensching 2000: 202).

(10) a. Tu non ti rallegri [CP aver io incontrata una morte] you not CL delight [ have-INF I found a death] 'You are not glad that I have found death.'

(Old Italian, D’Azeglio, ch. 18, p. 222, in Schwendener 1923:72)

b. Negar non voglio esser possible, [cP lui essere beato.. deny-INF not want be-INF possible him be-INF blessed 'I do not want to deny that it is possible that he is blessed.'

(Old Italian, Boccaccio, Dec., I, 1; cf. Schwendener 1923:82)

(11) [In convertendo Dominus captivitatem Sion] facti sumus

[in undoing Lord.NOM captivity.ACC Zion] made are

sicut consolati.

like dreaming

'When the Lord lets the prisoners of Zion go, we become like dreamers.'

(Vulgar Latin, Ps, 125, 1, cf. Kaulen 1904:299)

Summing up, there are several crucial observations to be made: (i) these are non-finite clauses, so there is no $\phi$-Probe, and, more specifically, no $\pi$-Probe; (ii) as adjunct or subject clauses, these are instances of unambiguous phasal domains; (iii) Case valuation is systematic and potentially influenced by linearization; (iv) the (C)-T domain lacks an intrinsic NOM value. 


\subsection{Phi-feature relevance and structural Case valuation}

Perhaps unsurprisingly, various cross-linguistic data suggest that $\phi$-features (and, crucially $\pi$ ) play a role in NOM but not ACC Case assignment (see also discussion in Szabolcsi 2007). In Romanian, for example, postverbal NOM DPs, whether subjects (12), or objects (13), trigger agreement (obligatorily in the standard variety, optionally in some regional dialects), but an ACC DP forces the default $3^{\text {rd }}$ singular verbal form (see 13).
a.
Vin / vine copiii
come.3PL / come.3SG child.PL-t
mîine.
come.3PL / come.3SG child.PL-the.NOM tomorrow
'The children are coming tomorrow.'
b. Copiii vin /*vine mîne.
child.PL-the-NOM come.3PL/ come-3SG tomorrow
a. Iţi plac fetele / ele $(/ *$ de fete $)$ ?
2SG.DAT like.3PL girl.PL-the.NOM / they (/ of girl PL.ACC)
b. Îţi place de fete?
2SG.DAT like.3SG of girl PL.ACC
'Do you like the(se) girls?'

Thus, only NOM DPs can agree and, as shown in (12b), agreement is obligatory when said DP is in Spec, TP, a fact also noted for Arabic (Al-Balushi 2011, Sitaridou 2002). However, I assume $[u \phi]$ on $\mathrm{T}$ is present throughout in (12)-(13). Consider next the Belfast English data from Henry (1995), discussed in Schütze (1997: 132-133):

(14) a. Usuns is happy.

b. $\quad$ We takes the bus.

c. Them's no good, are they / *are them?

What is noticeable in (14) is that lack of [u $\mathrm{u}$ ] on T forces ACC subjects, while presence of $[\mathrm{u} \phi]$ forces NOM subjects. ${ }^{14}$ Imbabura Quechua, an SOV language discussed in Cole and Jake (1978), points yet to a similar conclusion; data in (15) from Cole and Jake (1978:74).

$$
\begin{aligned}
& \text { a. Nuca-Ø can-da ricu-ni /*-ngui. } \\
& \text { I-NOM you-ACC see-1SG / } 2 \mathrm{SG} \\
& \text { 'I see you.' }
\end{aligned}
$$

\footnotetext{
${ }^{14}$ A related argument can be made from the behavior of Russian numeral subjects. Bošković (2006) discusses agreement patterns of these nominals which can either be GEN(itive) (i.e. genitive of quantification) or NOM. While GEN subjects can occur with either a default singular or show plural agreement, if the numeral subject is NOM, agreement is obligatory.

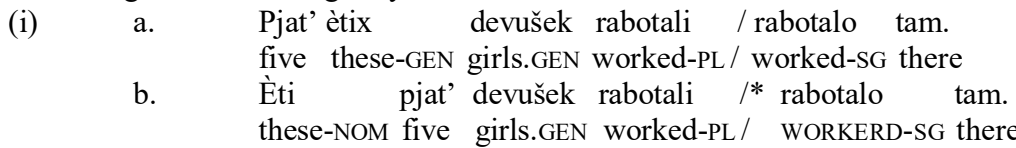

The author argues against optional agreement and concludes that agreement forces NOM Case on both NOM and GEN numerals. In effect, $\phi$-Probes trigger NOM values.
} 
b. Nuca-ta can-da ricu-naya-n $/ *$-ni $/ *$-ngui

I-ACC you-ACC see-DES-IMP / $1 \mathrm{SG} / 2 \mathrm{SG}$

'I would like to see you.'

In (15a), subject-verb agreement denotes phi-features on $\mathrm{T}$ and the subject is valued NOM. In (15b), with a desiderative clause and no agreement, both arguments are valued ACC.

To sum up, cross-linguistic data from unrelated languages show that phi-Probes are crucial for NOM values but irrelevant for ACC values. And, since past participles and adjectival predicates cannot assign Case, despite instances of gender and number agreement, the relevant phi-feature must be person $([\pi]) .{ }^{15}$ Consequently, structural Case values are licensed as in (16):

(16) a. NOM, if and only if the Probe is specified for $[\mathrm{uD}, \mathrm{u} \phi / \pi]^{16}$

b. $\quad \mathrm{ACC}$, if and only if the Probe is specified as [uD]

While (16) states that $[u \phi]$, as a phi-Probe containing $\pi$, plays the defining role in NOM Case valuation, it also shows that $\phi$-features are not a requirement of syntactic Case licensing. In addition, (16) allows for either ACC or NOM subjects, as these properties are now derived from the feature-al build up of the Probe, rather than reliant on specific heads, such as $\mathrm{T}$ or $\mathrm{v}^{*}$. (16) also assumes the absence of $[\pi]$ on $\mathrm{v}^{*}$; given the intrinsic deictic nature of $\pi$ and, therefore its links to the left periphery (see Bianchi 2008), this is perhaps expected. ${ }^{17}$ Nonetheless, (16) has nothing to say with respect to the parametrization observed in the data discussed in section 1.2. However, before furthering our analysis, we next briefly explore (and rule out) some alternate Minimalist approaches of Case realization. The next two sections discuss Case as a Tense equivalency and default Case mechanisms, respectively, and argue that neither approach suffices.

\section{Tense and Case values}

Consider Tense as a phasal property. Stowell (1982) argues that control infinitives in English are tensed, while their raising counterparts are not, and concludes that domains with a [+tense] feature on T are CPs and not just TPs. Various refinements exist in the literature, such as for example Landau's (2004) split into anaphoric and non-anaphoric (whether dependent or independent) $\mathrm{T}$, which takes into account issues such as finiteness. Crucially anaphoric $\mathrm{T}$ is never selected by $\mathrm{C}$, while non-anaphoric $\mathrm{T}$ has to be saturated by C. Suffice is to say that the C-T (phase-level) relationship seems to be the defining

\footnotetext{
${ }^{15}$ Uriagereka $(2006,2008)$ also focuses on the relevance of $\pi$ in relationship to Case.

${ }^{16}$ Nom includes non-default ABS, as discussed in Legate (2008).

${ }^{17}$ Note that Manzini and Savoia (2008) put forth a non-feature-based theory where they equate NOM with $\mathrm{D}$ (efiniteness) and ACC with $\mathrm{N}$ projections in the sentential tree. While very different from the proposal here, there is common ground in that $\mathrm{T}$ and $\mathrm{v}$ are no longer the locus of these Case values and also, in that NOM presupposes some deictic property.
} 
condition for temporal deixis (i.e. a non-anaphoric tense value) on $\mathrm{T}$, formalizable as $i \mathrm{~T}$, following Pesetsky and Torrego $(2001,2004 a) .{ }^{18}$

Since $\mathrm{C}$ licenses both Case and temporal deixis, one could capitalize on this correlation and argue that Case is "Tense", an avenue explored by, at least, Martin (2001), Pesetsky and Torrego (2001), Svenonius (2001), Haeberli (2002), Pesetsky and Torrego (2004a, b), and Alboiu (2006), However, this account runs into problems since even NOM Case values occur in the absence of Tense. Consider the Hungarian possessive construction, discussed by Szabolcsi (1983) and Kenesei (1986).

Kenesei (1986: 115) notes that NOM Case occurs in "two constructions in Hungarian: (a) in tensed sentences, and (b) in possessive constructions." The author further argues that Tense cannot be assumed to play a role in the latter situation and concludes that NOM is dependent on Agr ([u $\phi]$ here) given that an agreement suffix must appear on the head noun with possessives. The examples in (17) indicate the relevance of both $\pi$ and \# (number), so NOM valuation in Hungarian possessives is then unsurprising, in view of the presence of a $[\mathrm{u} \phi]$ Probe: ${ }^{19}$

$$
\begin{aligned}
& \text { a. a te ház-ad } \\
& \text { the you.NOM house-2SG } \\
& \text { 'your house' } \\
& \text { b. a fiú-k kapu-ja } \\
& \text { the boy-PL-NOM gate-3SG/PL } \\
& \text { 'the boys'gate' }
\end{aligned}
$$

(Kenesei 1986: 115)

(Kenesei 1986: 112)

In addition, while the non-finite clauses discussed in section 1.1.1 and 1.1.2 are of necessity phasal domains, it is unclear whether they all instantiate Tense. For example, Avram (2003) argues that semantic and syntactic properties of Romanian gerunds point toward an AspP status of these phrases. Semantically, they denote events (see also Pires 2001, for English), are verbal in nature but cannot combine with either a Neg head (i.e. the negative free morpheme $n u$ ) or a $\mathrm{T}$ head (i.e. auxiliaries) and to the extent that they license temporal adverbs, these adverbs denote time of event in the Reichenbachian (1947) sense, rather than time of reference. This seems compelling evidence for lack of a TP with Romanian gerunds. However, Alboiu (2007: 6), suggests these gerunds project to $\mathrm{CP}$, despite the absent TP domain, given the fact that they, (i) can combine with speakeroriented adverbs such as probably, which according to Cinque (1999) associate with epistemic modality, so are higher than Aspect, (ii) allow for topicalized subjects, which arguably target the left periphery of the clause (i.e. the CP domain, following Rizzi's 1997, 2004 cartographic approach), and precede clitics, which are part of the Inflectional

\footnotetext{
${ }^{18}$ For other references where Tense on $\mathrm{T}$ is a C attribute see also Dobrovie-Sorin (1994), Farkas (1992), Krapova (2001), Roberts and Roussou (2002), and Varlokosta (1994).

${ }^{19}$ On the phasal status of (possessive) DPs see Chomsky (2007, 2008), following Svenonius (2004), a.o.
} 
domain in Romance (Kayne 1991, Uriagereka 1995). ${ }^{20}$ Either way, Romanian phasal gerunds are tense deficient CPs but, nonetheless, trigger NOM Case valuation.

In conclusion, Case deficiencies cannot be readily construed as satisfiable by Tense any more than they can be construed as satisfiable by agreement. The phasal domain is the necessary condition for Case licensing and temporal deixis, if present, like agreement, is epiphenomenal.

\section{Lexical subjects and default Case}

Drawing on work by Marantz $(2000)$, Schütze $(1997,2001)$ poignantly argues that not all morphological Case forms are a reflex of syntactic abstract Case. More specifically, "the default case forms of a language are those that are used to spell out nominal expressions (e.g. DPs) that are not associated with any Case feature assigned or otherwise determined by syntactic mechanisms" Schütze (2001: 206). Such nominal expressions include adverbials, predicates, vocatives, left dislocated constituents, so, crucially, DPs not involved in an A-relationship.

However, while Schütze argues for cross-linguistic and language specific availability of default Case (e.g. ACC for English but NOM for Latin), he is careful to point out that wherever Case is determined by a syntactic mechanism, it cannot be default. For instance, Schütze (2001: 208) mentions that overt subjects in non-finite clauses in languages such as Irish and Latin cannot be attributed to the availability of default Case (contra Chung and McCloskey 1987), as the Case Filter would be vacuous if default Case were a syntactic feature. In sum, subject lexicalization in non-finite contexts cannot involve default Case.

Conceptual issues aside, there are also empirical problems with assuming default Case on lexical subjects. For instance, since Schütze (2001) argues that NOM is the default in Latin, the typically ACC overt subjects of non-finite domains - recall $(9 \mathrm{e})$ - must be valued syntactically.

Furthermore, Icelandic distinguishes between a default and a structural NOM, as evidenced by agreement facts (Sigurðsson 1991, 2008, 2009). More specifically, default agreement occurs in the presence of dislocated and vocative DPs, seen in (18a), but not with PRO subjects, shown in (18b). Consequently, I assume together with Sigurðsson $(1991,2008,2009)$ that non-finite NOM in PRO contexts is structural and not default (contra Boeckx and Hornstein 2006).

$$
\begin{aligned}
& \text { a. Strákurinn, við hann var ekki dansað } \\
& \text { boy-the.NOM with him.ACC was not dansaður } \\
& \text { 'The boy, nobody danced with him.' }
\end{aligned}
$$

(Sigurðsson 1991: 338)

\footnotetext{
${ }^{20}$ See also Dobrovie-Sorin (1994) and, especially, Motapanyane (1995) for a more comprehensive discussion that the gerundive verb in Romanian moves to the $\mathrm{C}$ domain. See section 4.1.1 for remarks on the status of preverbal subjects in Romanian.
} 

b. Pessi saga var skrifuð til [að PRO vera
this story.NOM.F.SG was written for to be-INF
lesin /*lesið].
read.NOM.F.SG $/ *$ DFT

(Sigurðsson 2008: 409)

In addition, according to Schütze (2001), both Swedish and German have default NOM, but neither language permits NOM subjects in infinitives (Sigurðsson, p.c.). And, lastly, in section 1.1, we saw that NOM-ACC micro-parametric variation in Old Italian infinitives is systematic and tied to linearization, ruling out ad hoc default insertion.

Summing up, while there is an undeniable place for default morphological Case in UG, there seems to be significant cross-linguistic evidence that any DP subject lexicalization is involved in systematic syntactic Case-checking mechanisms with valuation as outlined in (19). There are no syntactically default Case values.

(19) Checking [uCase] on DP arguments:

(i) [uCase] checked \& valued at first Merge $\rightarrow$ inherent Case value (e.g. DAT, GEN, ERG) $)^{21}$

(ii) $\quad$ DP is A-Probed $\rightarrow$ structural Case value:

$>\quad$ if Probe is specified for $[\mathbf{u D}, \mathbf{u} \phi / \pi]$, then NOM/ABS value

$>\quad$ if Probe is specified as $[\mathbf{u D}]$, then ACC value

(iii) [uCase] does not check at first Merge and DP is not A-Probed $\rightarrow$ [uCase] checked upon Transfer and no value ${ }^{22}$

(19) shows that abstract Case (both inherent and structural) presupposes an A-chain (i.e. a syntactic relationship). In this case, the morphological component receives "instructions" from the computational system and a specific DP value obtains as outlined in (19). ${ }^{23}$ If the DP fails to check [uCase] at first Merge and is not subsequently A-Probed, [uCase] deletes upon Transfer but DP lexicalization fails as there is no default value for abstract/syntactic Case. Consequently, attempting to lexicalize yields ungrammaticality, so only syntactic objects such as PRO, which are inherently silent, could be legitimate in these contexts.

The next task is to offer an implementation that can yield a principled account for morphological Case realizations in the data addressed here and preferably beyond. To this purpose, section 4 provides an explanation for the NOM-ACC valuation dichotomy for non-finite domains, section 5 addresses Case values on PRO, while Section 6 briefly tackles NOM objects.

\footnotetext{
${ }^{21}$ Note that, while I acknowledge Woolford's (2006) split into lexical and inherent case, I do not make that distinction here as my focus is primarily on "structural" Case valuation.

${ }^{22}$ Crucially, this also explains why, contrary to A-bar movement, A-movement operations are prohibited outside of their phasal domain (see Chomsky 2000 et seq.).

${ }^{23}$ This proposal is similar in spirit to Legate's (2008: 85), who states that "abstract Case features are determined in the syntax and realized in a postsyntactic morphology".
} 


\section{Null expletives as A-Probes}

In a system where phi-features are absent from non-finite $\mathrm{C}$, the question is what would ensure the $\phi$-specification (and, more specifically, the $\pi$ deficiency) assumed to associate with NOM values in languages with NOM lexical subjects in these domains?

It has been remarked (e.g. Ledgeway 1998, Sitaridou 2002) that only null subject languages have this property, but note that West Flemish is not, technically speaking, a null subject (i.e. pro-drop) language, since it only allows for null expletives (Haegeman, p. c.). Further support against the pro-drop connection comes from Western dialects of English (e.g. Newfoundland English, working-class Somerset English), which lack pro-drop but have null expletives (Ihalainen 1991) alongside NOM subjects, shown in (20).

(20) For he to listen to that talk was awkward.

(Newfoundland English, Ruth King, p.c.)

I argue that this null expletive connection is not accidental. More specifically, this uninterpretable phi-feature bundle, contains a person $(\pi)$ deficiency which guarantees a NOM value on its A-Probed associate, as shown in (4iiib), reintroduced as (21). ${ }^{24,25}$

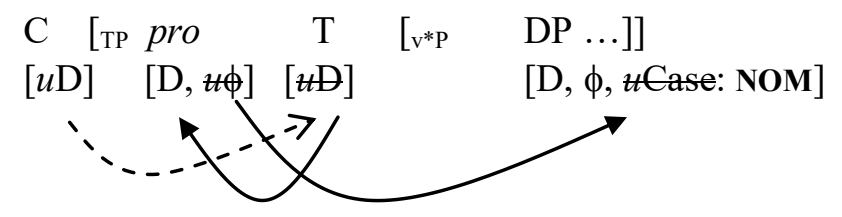

The empirical prediction of our analysis is that uninflected phasal domains can only license NOM syntactic values in languages with expletive pro. As Table 1 shows, the prediction seems to be borne out as we see a clear cross-linguistic correlation between null expletive languages and lexical NOM in non-finite contexts. We also see variation in some languages, which we address in Section 4.2. ${ }^{26}$ All instances of NOM are in bold.

\footnotetext{
${ }^{24}$ Chomsky (1981) introduces pro, an empty category that does not always bear the same array of featural specifications. On the one hand, there is the null subject of pro-drop languages, a nominal element that is referential and $\phi$-complete and enters the derivation in theta-assigning domains, on the other hand, there is a null expletive, which is non-referential, lacks intrinsic $\phi$-values and cannot be merged in theta-related positions. I assume that argumental pro is featurally specified as $[D, i \phi]$, so never a Probe, while the null expletive is featurally specified as [D, u $\phi]$, so, of necessity an A-Probe.

${ }^{25}$ As a D category, null expletives are potentially also specified for [uCase]. Nothing crucial hinges on whether this feature is present (or not), so I leave it out for ease of exposition. Chomsky's (1995:288) standpoint is that expletives are Caseless nominals but Chomsky (2004), following Lasnik (1999), revises this assumption for there, so the issue is unclear.

${ }^{26}$ Irish lacks conclusive evidence for a null expletive. In fact, Legate's (1999) analysis and discussed asymmetries with Romance provide evidence against it, as do analyses where Spec,TP is occupied by the predicate (Oda 2002).
} 
Table 1. Data summary for lexical subjects in non-finite CPs

\begin{tabular}{|c|c|c|c|}
\hline Language & $\begin{array}{l}\text { CP-internal Structural } \\
\text { NoM and ACC Case on } \\
\text { overt subject }\end{array}$ & $\begin{array}{l}\text { Null Subject } \\
\text { Language } \\
\text { pro }[\mathrm{D}, \mathrm{i} \phi]\end{array}$ & $\begin{array}{l}\text { Null } \\
\text { Expletive } \\
\text { Language } \\
\text { pro }[\mathrm{D}, \mathrm{u} \phi]\end{array}$ \\
\hline Ancient Greek & ACC, NOM & $\checkmark$ & $\theta$ \\
\hline Modern Greek & NOM & $\checkmark$ & $\checkmark$ \\
\hline Latin & ACC, NOM & $\checkmark$ & $\checkmark$ \\
\hline Old Italian & ACC, NOM & $\checkmark$ & $\checkmark$ \\
\hline Mod. Italian & NOM & $\checkmark$ & $\checkmark$ \\
\hline Romanian & NOM & $\checkmark$ & $\checkmark$ \\
\hline Spanish & NOM & $\checkmark$ & $\checkmark$ \\
\hline West Flemish & NOM & $*$ & $\checkmark$ \\
\hline Newfoundland English & ACC, NOM & * & $\checkmark$ \\
\hline Hungarian & NOM & $\checkmark$ & $\checkmark$ \\
\hline Czech & NOM & $\checkmark$ & $\checkmark$ \\
\hline Albanian & NOM & $\checkmark$ & $\checkmark$ \\
\hline Icelandic & * & $*$ & * \\
\hline German & $*$ & * & $*$ \\
\hline English & $\mathrm{ACC}$ & $*$ & $*$ \\
\hline Irish & ACC & * & * \\
\hline
\end{tabular}

\subsection{On expletive pro}

At this point we need to clarify (i) what triggers the presence of pro in the lexical array, and (ii) whether the "null" status of this expletive has any bearing on the issues at hand.

\subsubsection{Expletive pro in the lexical array}

Expletives are formatives devoid of any semantic content beyond their categorial status, so their presence presupposes a need for checking of purely formal features. Arguably, nominal expletives (whether overt or null) are made available by UG to check of the EPP of phasal heads, itself a structural requirement coerced by CI interface conditions (Chomsky 2006:14/2007). ${ }^{27}$

The factors driving pro insertion in the Numeration cannot be Case-related, as syntactic relevance of Case is not a property of Probes, just a computational visibility

${ }^{27}$ Alexiadou and Anagnostopoulou (1998) argue against null expletives (see also Manzini and Savoia 1997, 2002), suggesting instead that the EPP can be checked by verb raising to $T$ in languages without lexical DPs in Spec,TP. Crucially, this option is only available to languages where verbal agreement morphology includes the relevant nominal features required by the EPP. Since in non-finite domains verbs lack any nominal features, EPP checking must be assumed to resort to pro here. For further arguments for null expletive pro in Minimalism, see Torrego (1998), Cardinaletti (2004), Rezac (2004), Rizzi and Shlonski (2005), a.o. 
requirement on DPs. The expletive's role in Case-valuation is epiphenomenal, a welcome outcome of its $\phi$-deficiency. Checking EPP via expletive pro, ensures that the subject, a semantically relevant DP, is positionally flexible to occupy structural positions with various semantic and pragmatic relevance with the effect of what is often referred to as a "free word-order" language. ${ }^{28}$

For example, I have argued in previous work (Alboiu 1999, 2002, 2007) that Romanian exploits syntactic structure to encode information structure. In Alboiu (2002), I show that Romanian preverbal DPs are subject to a specificity effect, hence discourse configurationally displaced. ${ }^{29}$ However, for thetic sentences, VS(O) word order applies, irrespective of predicate type. Consider $(22 \mathrm{a}-\mathrm{c})$, which are appropriate answers to questions like, What happened?: ${ }^{28}$ Note that when pro is part of the lexical array, "Preference of Merge over Move" (Chomsky 2000: 104)
guarantees insertion of the null expletive in Spec,TP as opposed to dislocation of the thematic subject.
Alternatively, Uriagereka (2002) argues that any lexical item present in the numeration must make it to LF as
part of general conditions of Inclusiveness and Recoverability. Either way, inserting pro into the derivation
has theoretical precedence over subject dislocation.
${ }^{29}$ "Specificity" here refers to definite DPs or indefinite DPs with a referential, partitive, or a generic
collective reading (see de Hoop 1996). For examples see (i) from Alboiu (2000: 32):
a.
Prietena mea a obţinut o bursă în Franţa.
friend-F.SG-the my has obtained a fellowship in France
b. referential indefinite DP: 'My friend got a fellowship in France.'
$O$ prietenă de- a mea e lingvistă.
a friend-F.SG of GEN.F my is linguist-F.SG
c. A friend of mine is a ling
Doi peşti sunt negri (, al treilea e roşu).
two fish are black (, the third is red)
d. generic collective DP:
Trei peşti sunt mai scumpi decît doi.
three fish are more expensive than two.
'Three fish are more expensive than two.'

definite DP:

This specificity requirement holds for both unergative and unaccusative preverbal subjects in Romanian, as illustrated in (iia) and (iib), respectively.
(ii) a. (*Cinci pisici) au mîncat (cinci pisici).
( five cats) have eaten (five cats)
'Five cats have eaten.'
b. $\quad(*$ Cinci pisici) au plecat (cinci pisici).
( five cats) have left (five cats)
'Five cats have left.'

A preverbal subject would be licit in the above examples only if this DP could be understood partitively (i.e. as specific); in this case, there would be a set of known cats, out of which five are involved in the above predications. Unless the DP is somehow topical/“anchored" in the discourse (or contrastively focused - not shown here), it cannot appear preverbally. For similar observations, see Cornilescu $(1997,2000 \mathrm{~b})$ and Dobrovie-Sorin (1994), a.o. 

a. A sosit Victor.
AUX.3SG arrived Victor
'Victor arrived.'
b. A sunat Mihai.
AUX.3SG called Mihai
'Mihai called/phoned.'
c. L-a strigat Victor pe Mihai.
CL.3SGM.ACC-AUX.3SG shouted Victor pe Mihai
'Victor called Mihai.'

What is thus crucial for Romanian is that preverbal DP subjects cannot be assumed to dislocate for EPP considerations. In this language, I assume the EPP to be satisfied by expletive pro.

Various empirical and conceptual arguments can be made in support of expletive pro. Rizzi and Shlonski (2005: 1) argue that "criterial freezing", defined as the phenomenon whereby "an element moved to a position dedicated to some scope-discourse interpretive property, a criteria position, is frozen in place", can be obviated in the presence of expletives. (23), from Rizzi and Shlonski (2005: 11) shows this for English:

(23) a. *What do you think that $t_{\text {what }}$ is in the box?

b. What do you think that there is $t_{\text {what }}$ in the box?

Consequently, the well-formedness of (24a), presupposes a null expletive, pro (Rizzi and Shlonski 2005: 11). The Romanian facts in (24b) point to the same conclusion.

(24) a. Chi credi [che [ pro Subj vincerà $\left.\left.t_{\text {chi }}\right]\right]$

'Who do you think that will win.'

(Italian, Rizzi and Shlonski 2005: 11)

b. Cine crezi [că [pro va cisştiga $\left.t_{\text {cine }}\right]$ ?

Who think.2SG [that FUT.3SG win $\mathrm{t}_{\text {who }}$ ]

'Who do you think will win?'

(Romanian)

A brief look at generics in Romanian further reinforces availability of the null expletive in this language, especially for non-finite CP domains. Consider (25)-(26):
a. Păsările cîntă.
GEN, $\exists$
bird.PL-the sing.3PL.PRES
'Birds sing/are singing.'
b. Cîntă păsările. *GEN, $\exists$
sing.3PL.PRES bird.PL-the
'Birds are singing.' 


non-finite CPs: *GEN, $\exists$
a. Punea muzică [pentru a cînta păsările].
put-3SG.PST music [for INF sing bird-PL-the
'S/he'd play music for the birds to sing.'
b. [Cîntînd păsările], ne- am înveselit cu toţii.
singing.GER bird.PL-the CL.REFL1 PL have happified with all
c. [Păsările cîntînd], ne- am înveselit cu toții.
bird.PL-the singing.GER CL.REFL1PL have happified with all
'Because the birds were singing, we were all in a better mood.'
and not,
'Because birds sing, we were all in a better mood.'

According to Diesing (1992), while with episodic sentences subjects can be located in either Spec,IP (Spec, TP here) or Spec,VP (Spec, $v^{*}$ P here), with generics, these must raise out of the nuclear scope into the restrictive domain and thus occupy Spec,TP. (25) illustrates this for Romanian. In addition, the fact that (25b) is well-formed but cannot be interpreted as a generic also illustrates that subject DPs do not raise to Spec, TP at LF. ${ }^{30}$ The EPP must thus be satisfied by expletive pro. Crucially, in non-finite clauses, a generic interpretation is never possible, regardless of linearization (see (26c) and note that preverbal subjects are impossible in infinitives). We must thus conclude that expletive pro uniformly satisfies the EPP in Romanian non-finite CPs and that the preverbal subject is in a Topic position in (26c). These data explain why lexical subjects are exclusively valued with structural NOM and not ACC in this language.

To sum up, null expletive pro, is a parametrized UG primitive with an effect of semantico-pragmatic encoding and NOM Case valuation. ${ }^{31}$

${ }^{30}$ This is further reinforced by the data in (i), discussed in Alboiu (2002: 76), assuming Condition C to be operative at LF. See also Zubizarreta (1998), for Spanish.
(i)
a.
Azi [profesorul lui Victor ${ }_{\mathrm{i}} \mathrm{l}_{\mathrm{i}}$ -
a lăudat
today teacher-the his Victor CL.3SGM.ACC has praised
'Victor ${ }_{i}$ 's teacher praised him $_{\mathrm{i}}$ today.'
b. * Azi $1_{i^{-}} \quad$ a lăudat [profesorul lui Victor ${ }_{i}$.
today CL.3SGM.ACC has praised teacher-the GEN Victor

${ }^{31}$ Note that we need not worry about assuming that semantic and pragmatic factors can drive the derivation once these properties have grammaticized (i.e. have been assimilated by the computational system in an adequate manner). Note also that Chomsky's (2004) OCC feature is semantic in nature as are features such as Topic and Focus. In any case, in languages where preverbal subjects are semantico-pragmatically constrained, the EPP requirement must be assumed to check independently of these DPs. It is beyond the scope of this paper to explain why certain languages but not others resort to null expletives, but crucially, one must assume a split between the formative in Spec,TP and preposed subjects in languages such as Romanian. One direction might be to explore Cardinaletti's (2004) two-fold split of preverbal subject positions into a position hosting the subject of predication (i.e. the "notional" subject) and a purely formal position hosting the grammatical subject. Perhaps natural languages have the option of separating these positions or not. More specifically, a language such as Romanian would allow for both positions, with pro occupying the EPP position and semantically relevant preverbal DP subjects occupying the subject of predication position. In the absence of a notional subject, the latter position would not project. But, crucially Spec,TP would always host expletive pro. Conversely, languages such as English, which show no semantic restrictions on the DP in Spec,TP would not be assumed to distinguish between these two preverbal subject positions. A unique A-related position, i.e. Spec, TP, could perhaps also explain why English (and other languages lacking null expletives) has to resort 


\subsubsection{The relevance of "null"}

Under a view of late vocabulary insertion (adopted here), phonetic features are not available prior to Spell-Out. Should we then dismiss the "null" status of the expletive as syntactically irrelevant? I suggest that silence here is the result of the expletive's morphosyntactic deficiencies, so directly relevant. Arguably, $\phi$-featureless nominals have insufficient properties to warrant any morpheme insertion. Note that this is also true of PRO, also $\phi$-deficient. Under current assumptions, whereby PRO is Case-marked, its silence needs to be reconsidered. I follow Sigurðsson (2008) in assuming that variable reference and phi-features results in the impossibility of lexicalization and suggest that the same holds of the null expletive pro. ${ }^{32}$ Interestingly, what this entails is that overt expletives must have some degree of $\phi$-specification. Agreement facts show that French $i l$, English $i t$ and Icelandic $p a ð$, are all specified as $3^{\text {rd }}$ person singular neuter (for various discussion, see Chomsky 1995, Rezac 2004, and Rizzi and Shlonski 2005). Chomsky (2000) argues that English there is specified for $3^{\text {rd }}$ (or default) person but no number, with Kayne (2008) adding deixis as a property of there, and Rezac (2004) shows that Czech von is specified for person. This gives us (27):

$$
\begin{aligned}
& {[\mathrm{D}, u \phi] \quad[\mathrm{D}, \pi: 3, \#: \mathrm{SG}, \mathrm{g}: \mathrm{N}] \quad[\mathrm{D}, \pi: 3][\mathrm{D}, \pi: 3, u \#, u \mathrm{~g}]^{33}} \\
& \text { pro il, it, pad there von }
\end{aligned}
$$

Crucially, the lexicalized expletives in (27) have a $\pi$ value so overt expletives lack a role in Case valuation. Visibility of purely grammatical formatives indicates intrinsic properties.

\subsection{Structural Case valuation in non-finite domains}

The next subsections provide analyses for lexical subjects in non-finite CPs domains by looking at data from an exclusively NOM language (i.e. Romanian) and a typical ACC language (i.e. English). Micro-parametric variation within null expletive languages is also addressed.

\footnotetext{
to more feature-ally specified expletives, like there, instead. Note that such structural cross-linguistic asymmetries are mirrored elsewhere in the computational system. For instance, Pylkkänen (2008) argues that Japanese distinguishes between Spec,VoiceP and Spec,CauseP in the predicational domain, while English collapses these two postions. Note further that Rizzi and Shlonski (2005: 13) also view expletives as formal devices required by "discourse conditions" or "communicative intentions" and Tomić (2006) argues for null expletives as a property of languages that are structurally pragmatically oriented.

${ }^{32}$ Empirical evidence for its lack of phi-features comes from the fact that expletive pro can co-exist with post-verbal subjects in any person. Recall, for instance, (1a) and (3a) for $1^{\text {st }}$ person.

${ }^{33}$ Following Cardinaletti (1997), German es and Icelandic pað are generated in Spec, TP (IP) and moved to Spec,CP given that these do not invert with finite verbs (see also Sigurðsson 2008). Note also that any expletive assumed to be deictic (e.g. there, Kayne 2008), must bear a $\pi$ feature, as person is a prerequisite for deixis (Bianchi 2008).
} 


\subsubsection{Structural NOM subjects: The view from Romanian}

Section 4.1.1 showed that expletive pro uniformly satisfies the EPP in Romanian infinitives and gerunds, thus explaining the NOM nature of subjects. For illustration, consider the personal infinitive and gerund adjuncts in (28a) and (28b), respectively: ${ }^{34}$
a.
CP $*($ Pentru $)$
$[\mathrm{CP} *($ For $)$
$[* 2 . \mathrm{S}$
(*tu)
a avea tu
linişte], plecă.
'S/he left so that you can have peace of mind.'
b. $[\mathrm{CP}(\mathrm{tu})$ fiind $(\mathrm{tu})$ gata], am şi pornit.
[cP 2.SG.NOM be-GER 2.SG.NOM ready] have also started
'Once you were ready, we started on our way.'

(28a) shows that with infinitive adjuncts, a preposition-type complementizer (indicating the semantic clause type) is obligatory and that NOM lexical subject must occur postverbally. The lexical verb raises to $\mathrm{T}$ but not beyond as the infinitive particle ' $\mathrm{a}$ ', blocks subsequent $\mathrm{T}$ to $\mathrm{C}$ movement (Dobrovie-Sorin 1994). Schematically, these infinitives can be represented as in (29), with pro satisfiyng [uD] on $\mathrm{T}$. The unvalued features of the expletive establish a syntactic chain with the thematic subject, which at Spell-Out is valued NOM. Overt items are bolded.

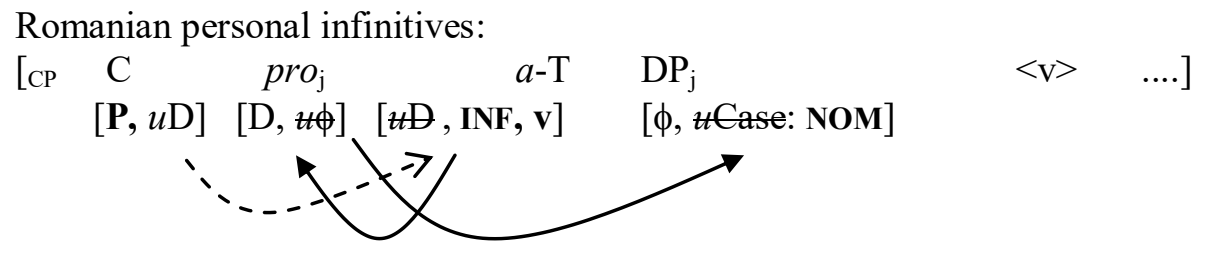

With gerunds, the subject may occur preverbally and the verb undergoes movement into the $\mathrm{C}$ domain. ${ }^{35}$ The representations in (30) show the EPP feature being transferred to Asp assuming $\mathrm{T}$ is absent (see Section 2). Unvalued $\phi$-features and Case check as for infinitives.

a. Romanian gerund adjuncts with VS linearization:

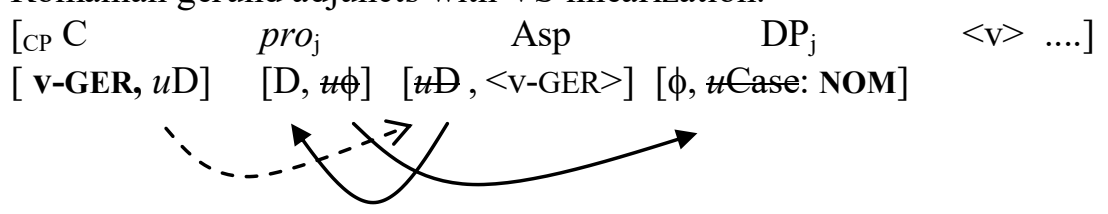

\footnotetext{
${ }^{34} \mathrm{Keep}$ in mind that the discussion focuses on phasal/CP non-finite domains. Reduced non-finite domains are irrelevant because subject lexicalization is not an internal property of the respective clause.

${ }^{35}$ I assume that LHM, as well as the presence of $\mathrm{P}$ with infinitives, is a direct manifestation of the presence of a syntactic relationship between $\mathrm{C}$ and its proxy head. This relationship could be triggered by properties of $\mathrm{C}$ (see Alboiu et al. 2015, Roberts and Roussou 2002, Pesetsky and Torrego 2001, 2004a), or it could be seen as a need of T to access features of the phase head (e.g. "tense anchoring", as in Ledgeway 1998, Poletto 2000, Varlokosta 1994 or A-related features, as in Belletti 1990, Rizzi 1982, Watanabe 1996).
} 
b. Romanian gerund adjuncts with SV linearization:

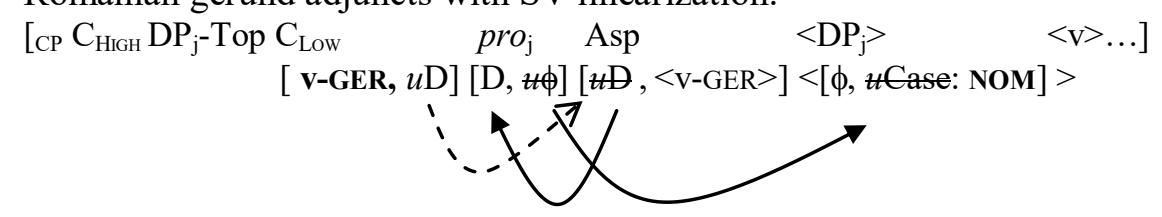

In addition, (30b) differs from (30a) in that it projects an expanded CP domain, with a Topic position sandwiched in-between a high $\mathrm{C}$ head (i.e. "Force") and a low C head (i.e. "Finite") to accomodate the topicalized preverbal subject (in the spirit of Rizzi 1997, 2004). While in (30b) the gerund only raises to a low $\mathrm{C}$ head, a high (phasal) $\mathrm{C}$ head must be present for $[\mathrm{uD}]{ }^{36}$

\subsubsection{Structural ACC subjects: The view from English}

There are two structural configurations where English lexicalizes ACC subjects: in for-to infinitives and clausal gerunds. (31) illustrates by resuming $(9 \mathrm{a}, \mathrm{b})$.

(31) a. [CP *(For) him to listen to that talk] was awkward.

b. [CP Him baking the pie] pleased everyone.

Focusing first on the infinitive, it is well known that for must be present or else PRO is forced. If a language like Romanian allows for a variety of prepositional complementizers with infinitives (e.g. pentru 'for/in order to', pînă 'until', de 'of'), determining the semantic function of the adjunct clause, and disallows these with subject infinitives, in English the presence of for is linked to the presence of a lexical subject, rather than to status or type of clausal infinitive. We return to this issue in section 5. (32) is a schematic representation for (31a):

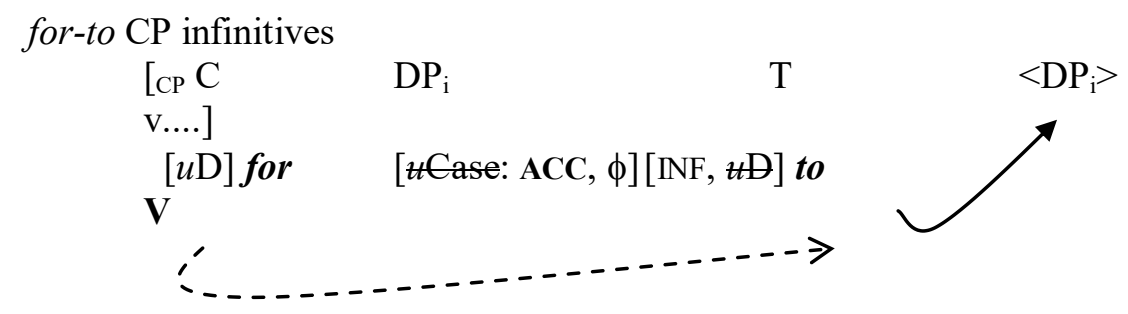

\footnotetext{
${ }^{36}$ Absolute participial constructions can be viewed as a sub-type of the gerund construction, where a be-GER is replaced by a null Asp head: (ia), is semantically equivalent to (ib).

(i)a. [CP Odată (fata $\quad /$ ea) $\varnothing$ deşteptată $\quad$ (fata $/$ ea) $], \ldots$

CP once (girl-the.NOM/she) ASP awake-PRTC-F.SG, (girl-the.NOM/ she)

b. [CP Fiind (fata / ea) <fiind> deşteptată (fata / ea)],.. CP be-GER (girl-the.NOM/she) ASP awake.-PRTC-F.SG, (girl-the.NOM/she)

I assume that the unaccusative vP in (ia) is selected by a null Aspectual head which lacks the GER specification. Consequently, no head movement to $\mathrm{C}$ can ensue and a stative adverb is inserted for semantic clause-typing, as seen for infinitives. Case-licensing is not affected.
} 
Given that there is no $[\mathrm{u} \phi]$ associated with the domain that probes but that an A-chain is established, via $[\mathrm{uD}]$ from $\mathrm{C}$, the subject DP lexicalizes as ACC.

Consider next clausal gerunds (CG, see Reuland 1983). Reuland (1983) and later Pires (2001) discuss five types of CGs, as in (33), illustrated in (34):

(33) a. ACC-ing as complements to verbs (34a).

b. ACC-ing as complements to subcategorized prepositions (34b).

c. ACC-ing in subject position (34c).

d. ACC-ing in constructions in adjunct prepositional phrases (34d).

e. Absolute constructions (34e-f).

(34) a. $\mathrm{I}_{\mathrm{i}}$ don't like [them / $\mathrm{PRO}_{\mathrm{i}}$ watching that much TV].

b. $\quad \mathrm{I}_{\mathrm{i}}$ asked about [them $/ \mathrm{PRO}_{\mathrm{i}}$ leaving tomorrow].

c. $\quad\left[\mathrm{Us} / \mathrm{PRO}_{\mathrm{i}} \text { leaving] saddened [our friends }\right]_{\mathrm{i}}$.

d. $\quad \mathrm{Sam}_{\mathrm{i}}$ found a wife [without/ after/ before (us / $\mathrm{PRO}_{\mathrm{i}}$ ) coming to town].

e. Mike expected to win the game, he / him being the best athlete in the school. (Pires 2006:3)

f. $\quad \mathrm{PRO}_{\mathrm{i}}$ being the idiot that he $\mathrm{i}_{\mathrm{i}}$ was, $\mathrm{John}_{\mathrm{i}}$ was unable to keep his $\mathrm{s}_{\mathrm{i}}$ job.

Cases (34a-d) instantiate a subcategorized CG situated in a canonically Case-marked position, an issue I return to shortly. (34e-f) are clausal adjuncts. Crucially, all these clauses license a subject, realized as a lexical ACC DP or as PRO. In addition, the absolute construction may license a NOM subject. Structurally speaking, adjunct and subject CGs are phasal domains, so can check off Case. Prepositions in English also select phasal domains (i.e. P or D), so the CGs in (34b, d) are nominal CPs. Lexical verbs may select non-phasal arguments in English (e.g. perception verbs and raising verbs), but given the possibility of obligatory control readings, I take the CG in (34) to also instantiate a C head. In conclusion, CGs have uniform CP status. ${ }^{37}$

The relevant literature on gerunds (Abney 1987, Chomsky 1981, Emonds 1970, Horn 1975, Moulton 2004, Pires 2001, Reuland 1983, among others) typically argues for -ing as either a nominal category or a participial category. However, I adopt a monosemic approach (see also Cowper 1995) and assume a single lexical entry for -ing, a category neutral affixal functor, unspecified for nominal or verbal status. The distinct properties associated with various -ing environments, result from other factors, such as intrinsic properties of insertion site (in the spirit of Marantz 2001). In CGs, the -ing GER(UND)/PART(ICIPIAL) feature merges high, as a $\mathrm{C}$ head, to denote the relevant clause type (i.e. its status as a gerund rather than, say, an infinitive clause).$^{38}$ However, this formative can also merge lower, as an aspectual non-phasal head (e.g. in domains selected by perception verbs or $\mathrm{T}$ heads). The affixal nature of this feature, corroborated by the absence of lexical verb raising in English, entails that -ing will always be

\footnotetext{
37 Pires (2001) argues these are TP domains but Reuland (1983) shows they can extrapose, allow wh-extraction and permit epistemic adverbs, all of which point toward a $\mathrm{C}$ domain and CP status.

38 -ing as a C head is far from new, as illustrated by some of Abney's (1987) structures.
} 
linearized lower than its initial Merge site (i.e. in the $\mathrm{v}$ domain or on the highest available verbal root). ${ }^{39}$

Nonetheless, a monosemic approach precludes a Case deficiency on -ing and does not explain the nominal nature of argument CGs. That CGs have DP status and can associate with Case-related positions is well-known given the asymmetrical data in (35): ${ }^{40}$
a. $\quad$ * Did [that he baked a cake] please everyone?
b. $\quad *$ Did [for Sam to act like that] look suspicious?
c. Did [him staying up late] upset you?

(35) shows that subject CGs but not finite or infinitive CPs may occupy Spec,TP. Suppose this reflects a null D head selecting the $\mathrm{CP} C \mathrm{CG}^{41}$ As a category neutral affix, -ing $\mathrm{C}$ can merge with a $\mathrm{D}$, but this is ruled out with infinitives and finite CPs which are verbal in nature. Furthermore, as an argument, this D head has [uCase]. See the schematic representation in $(36):^{42}$

a.

English object gerunds:

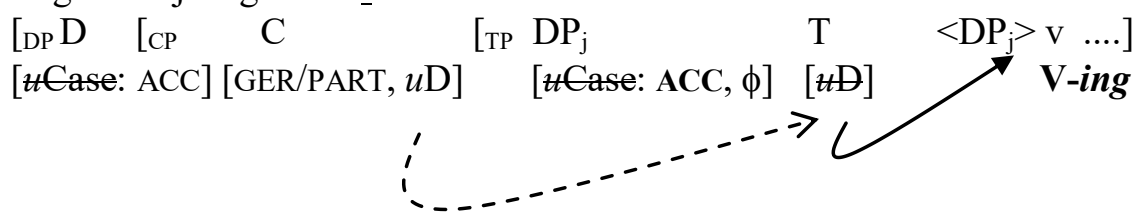

b. $\quad$ English subject gerunds:

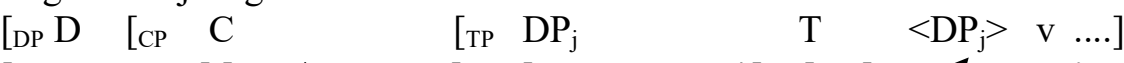

$$
\begin{aligned}
& \text { [uCase: NOM] [GER/PART, } u \mathrm{D}] \quad[u \text { Case: } \mathbf{A C C}, \phi] \quad[u \mathrm{D}] / \mathbf{V}^{-i n g} \\
& \therefore \ldots . . . . . . . . .-.
\end{aligned}
$$

${ }^{39}$ Abney (1987) proposes that the verb raises to -ing. Nonetheless, standard raising tests seem to indicate otherwise, as shown in (i):

(i) $\quad$ a. $\quad$ Him not being $(*$ not $)$ what we had hoped for $]$ did not matter.

b. $\quad$ Her never being $(*$ never $)$ late again] made a huge difference.

${ }^{40}$ For other DP related properties of gerunds, see McCawley (1988) and Pires (2007).

${ }^{41}$ This view is in line with Chomsky's (2008) analysis of gerunds as containing a [D V-ing] head moving to C and yielding a C/D head, with either $\mathrm{C}$ or D projecting (see also Hiraiwa 2005). However, in our analysis, a category neutral -ing merges directly in $\mathrm{C}$ and is selected by $\mathrm{D}$.

${ }^{42}$ Given the inherently indefinite nature of ACC-ing CGs (Portner 2002), I do not assume a phi-feature on the $\mathrm{D}$ head. Moreover, D, being indefinite, is non-phasal and so lacks any Case-licensing properties. Conversely, with Poss-ing gerunds, D is definite and presuppositional (Portner 1992), hence phasal and thus capable of checking (and valuing) Case. However, I do not discuss Poss-ing gerunds here as these do not expand to a CP domain (for discussion see Abney 1987, Chomsky 1981, Emonds 1970, Horn 1975, Moulton 2004, Pires 2001, Reuland 1983, among others). Given that sentences like His eating all the cake bothered Mary are felicitous in English, one must assume at least a $\mathrm{v}^{*} \mathrm{P}$ layer in POSS-ing gerunds (i.e. there is an external agentive argument, [D, $\phi: 3 \mathrm{SG} . \mathrm{M}, \mathrm{HCase:GEN]}$, as well as an ACC object, all the cake, so the $\mathrm{v}^{*}$ phasal layer is a must). Since this $\mathrm{V}^{* P}$ layer fails to project to $\mathrm{C}$ (see cited literature), there cannot be an ACC or NOM subject. Rather, the subject has its [uCase] feature checked at the D phasal level and receives the inherent GEN/POSS value that phasal D heads bestow in English. 
In effect, CG arguments are nominal CPs whose D head is valued as either ACC or NOM, in compliance with properties of the probing domain. ${ }^{43}$ Crucially, however, Case valuation of the null D does not affect ACC Case valuation of the subject internal to the CG (contra Pires 2007).

Let us now return to adjunct CGs (i.e. absolute constructions). In line with what I have developed so far, -ing has no Case deficiency so cannot be responsible for lexical subjects and NOM in non-finite CPs should only be available to grammars where null expletives are an option. While the ACC subject in (34e) is readily explainable as per (36) above, the NOM one less so.

First, note that there is variation in native speaker acceptance of (34e). To quote Michael Barrie (p. c.), "The 'he' versions sound like you're hyper-correcting for some 19TH century grammarian." To quote an anonymous reviewer, "*Roddy tried to avoid Elaine, him being a confirmed bachelor is dreadful". To cite an example from Schütze (1997: 56), "Him/*he liking beans, they bought some." What to make of the data then? Clearly, judgments vary from unacceptable, to prescriptive, to required. I suggest that these structures have dubious current productivity and are a relic of a time when the grammar of English allowed for a null expletive. Earlier stages of English (i.e. Old and Middle English), while not fully pro-drop, had null expletives (Fischer et al., 2000). However, while null expletives disappeared in Early Modern English, the NOM absolute construction did not. The construction was perpetuated by prescriptive grammarians, so that we can assume that some speakers have "learnt" to allow for a null expletive in just these constructions despite the fact that a null expletive is no longer active in standard English. Crucially, exactly as our analysis would predict, ACC subjects start to appear alongside the NOM in the $16^{\text {th }}$ and $17^{\text {th }}$ centuries (Poutsma 1929), so precisely around the time that English lost the null expletive. This explains the variation in judgments, as well as the telling prescriptive flavour. It also accounts for why NOM in non-finite CPs in English occurs in just these contexts and varies with ACC. Furthermore, given low (i.e. in $\mathrm{v}$ *P domain) lexicalization of the GER/PART feature, linearization is uniformly SV, regardless of subject status.

\subsubsection{Variation in subject lexicalization}

This section briefly focuses on Old Italian infinitives which, following Mensching (2000), allows for both lexical ACC and NOM subjects, with postverbal subjects strictly NOM. This micro-parametric variation should not surprise since availability of $[D, u \phi]$ in the mental lexicon is not necessarily synonymous to its insertion in the lexical array. Assuming that discourse conditions determined whether $[\mathrm{uD}]$ was checked via expletive

\footnotetext{
${ }^{43}$ Evidence for CP-internal ACC Case assignment/checking comes from the inability of these ACC subjects to passivize (i.e. move to Spec,TP of the main clause) discussed in Cornilescu (2003: 439). Compare (ia), containing a small clause participial, with (ib), containing a gerund:

(i) a. $\quad \mathrm{He}_{\mathrm{i}}$ was found $\left[\mathrm{sc} \mathrm{t}_{\mathrm{i}}\right.$ dead / sleeping].

b. $\quad * \mathrm{He}_{\mathrm{i}}$ was regretted $\left[\mathrm{CP} \mathrm{t}_{\mathrm{i}}\right.$ leaving].
} 
pro or subject DP dislocation, I suggest the representations in (37) for the data introduced in $(2 \mathrm{a}, \mathrm{b}) \mathrm{:}^{44}$

a. Old Italian infinitives with pro:

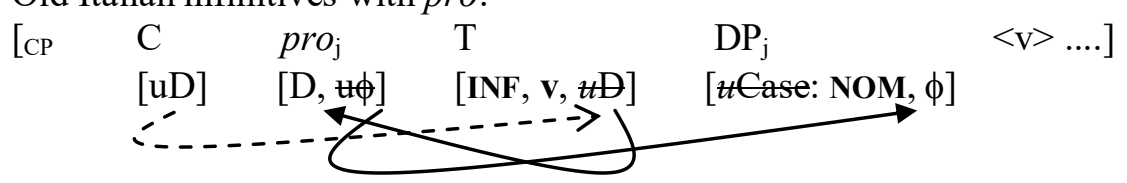

b. Old Italian infinitives without pro:

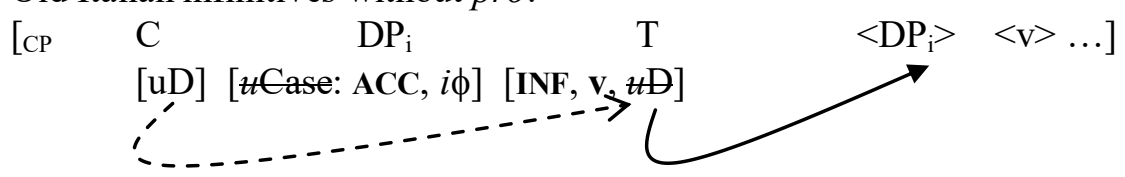

In $(37 \mathrm{a})$, the $[\mathrm{uD}]$ feature transmitted from $\mathrm{C}$ to its $\mathrm{T}$ proxy head is satisfied by external Merge of the expletive, with NOM consequences for the subject, while in (37b), this feature is satisfied by the subject istelf, with ACC consequences. Furthermore, akin to what we saw for Romanian gerunds, Old Italian NOM subjects were also attested preverbally in these infinitives, so without Aux-to-Comp (LHM). See (38a), schematically represented as in (38b):

(38) a. perchè io disso [io aver trovato iscritto ...]

because I said I have-INF found written

"because I said that I had found that it was written ..."

(Mensching 2000: 133, Malispini, ch. $42,13^{\text {th }}$ c.)

b. Old Italian infinitives with pro and subject fronting:

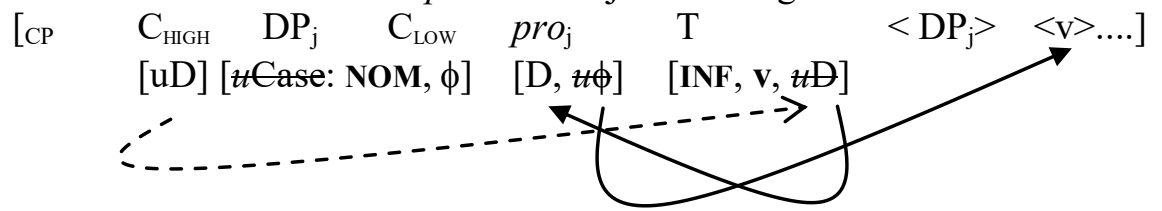

The representation in (38b) indicates movement of the thematic subject into the CP, left-peripheral domain. I leave open the question of locus of movement given that we do not have the tools to determine interpretative differences. ${ }^{45}$

To sum up then, expletive pro-availability does not automatically guarantee insertion in the lexical array and various language specific phenomena might either prevent or require its presence in the Numeration.

\footnotetext{
${ }^{44}$ I assume a similar explanation for Case variation in Latin gerunds. While subjects are mainly lexicalized as ACC, the postverbal subject in (11) is, unsurprisingly, NOM.

${ }^{45}$ Note that in standard modern Italian lexical subjects in uninflected CPs are restricted to Aux-to-Comp (LHM) constructions (Belletti 1990, Rizzi 1982), with preverbal subjects ruled out. This suggests a diachronic shift. Specifically, the left peripheral field in modern Italian non-finite CPs must be more limited, with less available XP positions than in Old Italian and a single $\mathrm{C}$ head (akin perhaps to Romanian infinitives).
} 


\section{PRO}

It is by now well-known that covert subjects, such as PRO, trigger Case concord on various types of elements (e.g. predicates, quantifiers, participles), fact taken as evidence of PRO bearing Case (e.g. Adger 2007, Bobaljik and Landau 2009, Cecchetto and Oniga 2004, Landau 2008, Schütze 1997, Sigurðsson 1991, 2008). As discussed, I assume that, as an argument DP, PRO is equipped with [uCase] and can get structural or lexical/inherent Case (contra Chomsky 1982, Chomsky and Lasnik 1995, Uriagereka 2008). The challenge rests in explaining the facts. ${ }^{46}$

\subsection{Formal features of PRO}

The first task is to understand what makes PRO 'PRO'. Given that PRO and (c) overt pronouns are arguments, while expletives are not, I assume that the former but not the latter require a referential index, [R]. Note that referentiality is distinct from phifeatures, as shown in (39). ${ }^{47}$

(39) a. $\quad \operatorname{Dan}_{\mathrm{i}} \operatorname{saw}_{\operatorname{him}_{\mathrm{j}} *_{\mathrm{i}}}$ in the car.

b. Every woman ${ }_{i}$ sat on the chair in front of her ${ }_{i j}$.

In (39a) Dan and him display identical $\phi$-features but cannot be coindexed, while in (49b), her ${ }_{i}$ is a bound variable without reference to any specific individual. However, while pronouns have variable reference/extensions, their $\phi$-features are fixed, so they have stable intensions. PRO, on the other hand, has both variable extension and variable intension, as shown in (40). ${ }^{48}$

$$
\begin{aligned}
& \text { a. PRO: [D, uCase, } \alpha \phi, \alpha \mathrm{R}] \\
& \text { b. argumental pro: }[\mathrm{D}, \mathrm{uCase}, \mathrm{i} \phi, \alpha \mathrm{R}]
\end{aligned}
$$

Furthermore, PRO's deficiencies cannot be "uninterpretable" features (i.e. [u申], [uR]) since neither PRO nor anaphors act as Probes (i.e. they have to be in the c-command domain of their licenser and not vice versa). Hence, their variable status is reflected by $[\alpha]$. Despite the fact that treating PRO uniformly as an $[\alpha \phi]$ runs counter to traditional GB proposals (Chomsky 1981, 1982) which assume a split between an anaphoric and a pronominal PRO, such an approach is in line with much current work (e.g. Kratzer 2009, Landau 2001, 2004, Sigurðsson 2008). It also arguably explains the silence of PRO whether controlled or not.

\footnotetext{
${ }^{46}$ I do not discuss cases where PRO bears the Case of its controller as in these instances it is arguably difficult to maintain Case-assignment within the non-finite clause. Presumably, some Case transmission mechanism is at stake, implementable in a variety of ways (e.g. Hornstein 1999, Landau 1999, 2008, Pires 2007, inter alia).

${ }^{47}$ See also Baker (2008:31) for the relationship between referential indexing and phi-features.

${ }^{48}$ For similar remarks, see also Sigurðsson (2008). See Chierchia (1989), Hornstein (1999) for de se readings in OC (hence, variable intension).
} 
Once we assume that PRO is Case-marked, its lack of visibility must be otherwise accounted for. Sigurðsson (2008: 424) suggests that PRO "cannot carry $1^{\text {st }}$ or $2^{\text {nd }}$ person except under control" and argues that its silence is due to a lack of a $\pi$ feature. ${ }^{49}$ So, in Sigurðsson's spirit, I assume that $[\alpha \phi]$ (i.e. variable intension) is what prevents PRO lexicalization, whether controlled or logophoric, as in (41), despite its satisfied Case properties: ${ }^{50}$

(41) $\left[\mathrm{PRO}_{\mathrm{i}}\right.$ to improve myself $\left.\mathrm{i}_{\mathrm{i}}\right]$ is a permanent goal.

To complicate matters, there do seem to be instances which arguably allow for PRO lexicalization. However, PRO can only obviate its silence when there are other features at stake: specifically, when PRO has wh-operator status (42b) and/or is focused/emphasized (42c), the latter property bringing PRO in line with other anaphors which typically lexicalize only under emphasis. Example (42a) shows croire 'believe' to be a control predicate in French and (42b) shows qui 'who' in the stead of PRO, while (42c) is an example of focused overt PRO in Romanian:
a. $\quad \mathrm{Je}_{\mathrm{i}}$ crois $\left[\left({ }^{*}\right.\right.$ Georges $) / \mathrm{PRO}_{\mathrm{i}}$ être le meilleur $]$. 'I believe to be the best.'
b. Qui crois-tu être le meilleur? 'Who do you believe to be the best?'
c. [CP A fi (*doar/numai) tu present la adunare] [CP INF be only 2.SG.NOM present at meeting] e de neconceput. be.PRES.3SG of inconceivable 'It's inconceivable that you be the only one present at the meeting.'

PRO visibility then is incumbent on additional features. Having discussed PRO's feature-al build up, as well as its silence, I next address its Case checking.

\subsection{On Case and PRO}

Since PRO lexicalization is extremely limited (e.g. never possible in Icelandic, Freidin and Sprouse 1991, Sigurðsson 2008, a.o.), other factors have to be taken into account when determining the Case of PRO. Typically, these have focused on the Case of a nominal or adjectival predicate, quantifier, or some other syntactic object associated with PRO. (43) offers some relevant cross-linguistic data:

\footnotetext{
${ }^{49}$ See also Schütze (1997) for suggestions that PRO's silence is semantic rather than syntactic.

${ }^{50}$ Legate (2008: 86) revisits data from Freidin and Sprouse (1991) which shows that even a quirky Dative subject PRO cannot be lexicalized in Icelandic. Under the approach assumed here, PRO's silence is no longer striking.
} 
(43) a. Strákarnir ${ }_{i}$ vonast til [að $\mathrm{PRO}_{\mathrm{i}}$ leiðast ekki öllum í skóla]. boys-NOM hope for [to PRO.DAT bore not all-DAT in school] 'The boys hope not to be all bored in school.'

b. Hún bað Ólaf ${ }_{\mathrm{i}}$ (Icelandic, Sigurðsson 1991, in Landau 2003: she.NOM asked Olaf.ACC [to PRO.NOM go just alone.NOM to veisluna] party-the

'She asked Olaf to just go alone to the party.'

(Icelandic, Sigurðsson 2008: 414)

c. [að PRO vera ríkur] er ágætt.

to PRO.NOM be rich.NOM is nice

'It's nice to be rich.'

d. Ivan ne znaet [kak tuda PRO dobrat'sja odnomu]

Ivan.NOM not know [how there PRO.DAT reach-INF alone-DAT]

'Ivan doesn't know how to get there by himself.'

e. [PRO philanthropon] einai dei

(Russian, Landau 2008: 884) friendly.ACC.3SG be-INF must-3SG

'One needs to love people.'

(Ancient Greek, Isocrates, II: 15, adapted from Sevdali 2005: 137)

The idea here is that PRO agrees with its predicate, quantifier, and so on, so would bear the same Case value. However, it turns out that such an assumption is problematic. For instance, given data like (43d), Landau (2008) argues that non-finite C assigns DAT Case in Russian. Nonetheless, this is difficult to maintain in view of the fact that Russian predicates also surface with Instrumental Case in both non-finite, (44a), and finite CPs, (44b), and that Case on the adjectival predicate does not always match Case on the subject, see $(44 \mathrm{c}, \mathrm{d})$ :

(44) a. Harasho [CP PRO byt bogatym] nice be.INF rich-INSTR

'It is nice to be rich.'

b. (Ja) bogatiy.

1.SG.M.NOM rich-NOM

'I am rich.'

c. (Ja) byl bogatym.

1.SG.M.NOM be.PAST rich-INSTR 'I was rich.'

d. (Ja) budu bogatym.

1.SG.M.NOM be.FUT rich-INSTR

'I will be rich.' 
The data in (44) suggest two things: (i) Case-transmission between the subject and the predicate is not obligatory and (ii) INSTR Case is a property of the predicate domain, perhaps correlated with presence or absence of the copula, rather than a property of $\mathrm{C}$ (or aspectual properties, as suggested in Richardson 2007). In the absence of conclusive evidence of Case transmission, we lack strong evidence for either INSTR or DAT PRO in Russian. ${ }^{51}$

The point here is that the morphological Case of (secondary) predicates need not agree with that of the DP (see also Richardson 2007) and may not always be a clear indication of what goes on with PRO. We could be dealing with dedicated predicative Cases, as suggested by Irimia (2009), or perhaps default Case, as hinted at by Schütze (1997) for English ACC pronominal predicates. In any case, the empirical data are not as reliable as we would like.

So where does that leave the Case of PRO? I suggest that we rely instead on (i) the morphological Case of quantifiers as, assuming these are part of the nominal domain, they represent an instance of Case concord, (ii) Case available to the domain of PRO occurrence and (iii) lexicalization of PRO. Icelandic data from (i) support quirky/inherent Case on PRO (references cited). With regards to (ii), there is evidence for structural NOM from Icelandic where, in addition to the presence of non-default NOM on predicates (see data in (18a-b)), structural NOM occurs on objects with quirky subjects; to this purpose, consider the Icelandic example in (45) from Freidin and Sprouse (1991:409) reintroduced in Legate (2008: 86).

$$
\begin{aligned}
& \text { Að PRO batna veikin er venjulegt. } \\
& \text { to PRO.DAT recover from-INF disease-the-NOM is usual } \\
& \text { 'To recover from the disease is usual.' }
\end{aligned}
$$

Crucially, (45) shows that structural NOM is available in Icelandic PRO infinitives, such that, in the absence of quirky Case, PRO would bear a NOM value. In addition, we saw "lexical" PRO occurring in the NOM form in both the Romanian and the French examples in (42).

To conclude, there seems to be sufficient evidence to warrant an account for structural NOM on PRO in non-finite domains. ${ }^{52}$ The next section addresses this issue, but first a disclaimer. Specifically, given the pragmatic role attributed to expletive pro, this nominal is never selected from the lexicon in derivations with PRO: when null, a DP cannot be relevant for discourse properties, so expletive pro would be futile with PRO subjects. Which means that an alternate analysis than the one developed for lexical subjects in section 4 is in order for NOM on PRO.

\subsection{Deriving NOM PRO}

It is well-known that PRO is available to CP not TP (IP), hence exclusively phasal, domains. Now, according to the Phase Impenetrability Condition (Chomsky 2000, 2001),

\footnotetext{
${ }^{51}$ Note that the same logic carries over to the AG data.

${ }^{52}$ NOM for PRO was (to the best of my knowledge) first proposed by Sigurðsson (1991).
} 
only the Edge of the Phase is visible to the outside domain. Since PRO is not an Operator, it will fail to raise to the Phase Edge. However, since PRO has both variable intension and extension, it needs a value for these features (i.e. a referential and a phi-index), so must associate with relevant material outside of its Phase. This apparent contradiction provides us with conceptual motivation for postulating the presence of a Logophoric Operator $\left(\mathrm{OP}_{\mathrm{LOG}}\right)$ in Spec,CP in all such derivations. ${ }^{53}$ This $\mathrm{OP}_{\mathrm{LOG}}$ has a human orientation, hence phi (including person) and referential features controlled either by discourse (D), with the result of a $\left[\phi_{D}, R_{D}\right]$ value, or a matrix argument, with the result of $\left[\phi_{i}, \mathrm{R}_{\mathrm{i}}\right]$. The presence of $\mathrm{OP}_{\mathrm{LOG}}$ ensures that PRO is locally bound (as is fit for an anaphor) and solves the Edge problem. Interestingly, the $\mathrm{OP}_{\mathrm{LOG}}$ provides an elegant way of reconciling some otherwise apparently contradictory data, so is also empirically motivated.

Baltin (1995) discusses data of the type in (56) which essentially shows that PRO does not raise to Spec,TP (i.e. does not move out of VP) in English. If it did, the quantifier in (46b) would be adequately c-commanded and the outcome should be grammatical, contrary to fact.

a. [To PRO all leave now] would be unthinkable.

b. *[All to PRO leave now] would be unthinkable.

Conversely, the legitimacy of (47) seems to indicate PRO movement outside of its initial Merge position (i.e. to Spec, TP of the raising predicate) or the reflexive should be ruled out:

$$
\begin{aligned}
& \mathrm{John}_{\mathrm{i}} \text { promised his psychologist }\left[\mathrm { CP } _ { \mathrm { PRO } } \text { to seem to himself } \mathrm { P } _ { \mathrm { i } } / * \text { herself } \left[\angle \mathrm{PRO}_{\mathrm{i}}>\right.\right. \\
& \text { to be competent] before leaving therapy]. }
\end{aligned}
$$

(example offered by an anonymous reviewer)

The presence of $\mathrm{OP}_{\mathrm{LOG}}$ in $\mathrm{Spec}, \mathrm{CP}$ provides a straightforward account for both the ungrammaticality of (46b) and the well-formedness of (47), without PRO dislocation. $\mathrm{OP}_{\text {LOG }}$ licenses the reflexive in (47) just as it licenses in-situ PRO, see (48). However, following Rezac (2010) who argues for the inability of agreement (phi-features) to license floating quantifiers, $\mathrm{OP}_{\mathrm{LOG}}$ cannot license all in (46b).

$$
\mathrm{John}_{\mathrm{i}} \text { promised his psychologist [CP } \mathrm{OP}_{\text {LOGi }} \text { to seem to himself } \mathrm{f}_{\mathrm{i}} / \text { } \text { herself [ to [vP }
$$$$
\mathrm{PRO}_{\mathrm{i}} \text { be competent]] before leaving therapy]. }
$$

I further suggest that $\mathrm{OP}_{\mathrm{LOG}}$, as a syntactic object equipped with phi-features, plays a role in NOM Case valuation. The proposed analysis is similar in spirit to what we have seen for lexical subjects and expletive pro with the difference that the Operator does not function as a Probe. Rather, given requirements of Spec-Head agree, these features are

\footnotetext{
${ }^{53}$ See also Manzini and Roussou (2000). For an alternate view, see Landau (1999, 2001, 2004, 2008, 2013). Given that Landau's analysis relies on the presence of $[u \phi]$ in infinitives, his is not a viable option under the current analysis where these features are missing on non-finite $\mathrm{C}$.
} 
also present on $\mathrm{C}$ and, by feature-inheritance, $\mathrm{T}$. If correct, such an account would amount to structural NOM values cross-linguistically on all instances of A-probed PRO in the absence of inherent Case. ${ }^{54}$ In (49), I illustrate with previously introduced data from Icelandic:

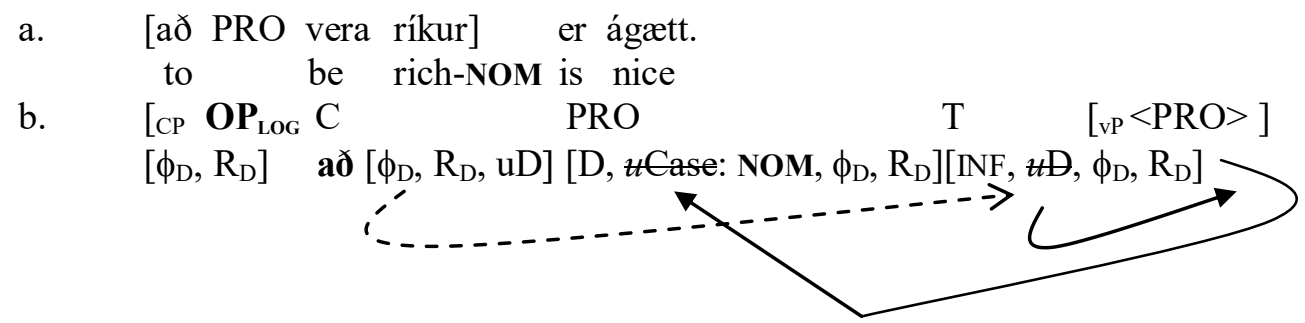

A central tenet of the above analysis is the fact that PRO is involved in an A-chain. However, for English, having decided that PRO does not dislocate to Spec,TP, the account in (49b) cannot be maintained (i.e. English PRO is not A-Probed). A notable difference between languages like Icelandic and English is that in the former, there is overt evidence in control constructions for a $\mathrm{C}$ domain distinct from $\mathrm{T}$. In English such evidence is missing. Compare the data in (50a-b):
a. Ég harma að pegar hafi María lesið pessa bók. I regret that already has María read this book 'I regret that Mary has already read this book.'

(Icelandic, Roberts 1993:59)

b. $\quad\left[\mathrm{CP}(*\right.$ For $)$ to $\mathrm{PRO}_{\text {arb }}$ give up now] was unthinkable.

The Icelandic complementizer $a ð$ is not specific to control infinitives but occurs equally with finite domains, see (50a), where its function is equivalent to English that. Crucially, this is a $\mathrm{C}$ element. In standard English, on the other hand, the infinitive complementizer for cannot occur in control structures, see $(50 \mathrm{~b})$. Now, if $\mathrm{C}$ projected independently of $\mathrm{T}$ in English infinitives, we would have no principled explanation for why for is ruled out in (50b).

We can assume that lack for lexicalization in (50b) denotes a merged $\mathrm{C} / \mathrm{T}$ domain (i.e. one head). Note that in generative grammar merged heads presuppose (i) feature sharing (i.e. an infinitive value here) and (ii) lack of an intervening specifier (e.g. Culicover 1999, Giorgi and Pianesi 1997, Haider 1988), in English control supported by in-situ PRO. Failure of these heads to launch separately would thus of necessity denote the absence of an A-Probe for PRO.$^{55}$ The [uCase] feature on PRO would thus remain unchecked in syntax but delete upon Transfer as the phasal domain is the necessary and

\footnotetext{
${ }^{54}$ See also Baltin and Barrett (2002).

${ }^{55} \mathrm{I}$ have no explanation as to why English behaves this way but it is worth noting that a merged $\mathrm{C} / \mathrm{T}$ account would also readily explain lack of $d o$-support with $w h$-subjects, and absence of an elaborate left-edge cartography as in Rizzi (1997, et seq.). Note that the necessary presence of an $\mathrm{OP}_{\text {LOG }}$ also satisfies the EPP CI interface condition (which I assume universal), pre-empting transfer of a $[\mathrm{uD}]$ feature on $\mathrm{T}$.
} 
sufficient condition for Case licensing. ${ }^{56}$ Hence, a derivationally unchecked Case feature will be unproblematic for LF. In addition, given that PRO is in the c-command domain of the $\mathrm{OP}_{\mathrm{LOG}}$, its intension and extension will be appropriately valued at LF. For a schematic representation, see (51):

$$
\begin{aligned}
& \text { English Prepositionless CP infinitives } \\
& \begin{array}{lllll}
{[\mathrm{CP}} & \mathbf{O P}_{\mathrm{LOG}} & \mathbf{C} / \mathbf{T} & \mathrm{PRO} & \\
& {\left[\phi_{\mathrm{D}}, \mathrm{R}_{\mathrm{D}}\right]} & \text { to }[\mathrm{INF}] & {\left[\mathrm{D}, \boldsymbol{t}_{\text {Case: }} \mathbf{A C C}_{\mathbf{D E F}}, \phi_{\mathrm{D}}, \mathrm{R}_{\mathrm{D}}\right]} &
\end{array}
\end{aligned}
$$

This analysis of Case-checking whereby Spell-Out can erase [uCase] from arguments without causing the derivation to crash does not renege on the Case Filter since crucially lexicalization is ruled out in these contexts, as is well-known and seen in (52): ${ }^{57}$

(52) a. *To me/her/him give up now is unthinkable.

b. For me/her/him to give up now is unthinkable.

Note that (52a) can only be a Case Filter violation as nothing requires the presence of $\mathrm{PRO}$ in this derivation. Compare with $(52 \mathrm{~b})$, where $\mathrm{C}$ projects independently of $\mathrm{T}$, the DP is A-Probed and the ACC form is inserted as discussed in Section 4.2.2.

To sum up, I have argued for the presence of a Logophoric Operator in all control constructions. If PRO is A-Probed outside of its $\mathrm{vP}$, it is always assigned a NOM value.

\section{Predictions beyond non-finite CP domains}

If this analysis is on the right track, we can in principle expect to see languages (or dialects or specific grammatical constructions) where subjects and objects have the same Case or where subjects can be ACC in finite CP domains and objects can be NOM with phasal $\mathrm{v}^{*} \mathrm{P}$. Interestingly, these predictions are borne out.

In Khoekhoe (Central Khoisan, spoken in Namibia), for example, the subject and object both have the same Case in interrogative contexts, as illustrated in (53):

\footnotetext{
${ }^{56}$ Note that $\phi$-features also seem to delete upon Transfer if unvalued as evidenced by data with quirky subjects (which do not agree) in languages like Icelandic, Old English, and Romanian, among others. In such cases, a default 3sG is lexicalized, as in (i).
(i) Îţi place de fete?
2SG.DAT like.3SG of girl-PL.ACC
'Do you like the(se) girls?'

Note that SG number and 3 person (or absence of person, following Benveniste) are universal defaults, so inserted without problems. There is presumably no such equivalent for Case which only allows for language specific values.

${ }^{57}$ This, in a sense, vindicates Chomksy and Lasnik's 1993 “null Case” account for PRO, at least for English.
} 


$$
\text { axa }-\mathrm{p} \quad \text {-a } \quad \text { ko } \quad !^{\mathrm{x}} \mathrm{o} \quad \text { ani }-\mathrm{s} \quad \text {-a } ?^{58}
$$

child-M.SG-OBL RCT.PST catch bird-F.SG-OBL

'Did the boy catch the bird?'

While this Case is referred to as "oblique" in the descriptive literature, it is valued in the absence of $[u \phi]$ on either $\mathrm{T}$ or $\mathrm{v}$, so for our purposes is ACC. This is reminiscent of the Imbabura Quechua data in (15) and, generally, discussion in section 1.2.

Returning to West Country varieties, including Newfoundland English, these show what is referred to as "pronoun exchange" in the descriptive literature, such as use of NOM where one would expect ACC. Consider (54):

(54) a. She pushed I down.

b. Pass he over to me.

The typical explanation in the literature is that NOM replaces ACC whenever there is emphasis. Under our proposal, the object DP surfaces with NOM if and only if the probing domain involved in assigning Case (i.e. $v^{*}$ ) contains [u $\left.\phi\right]$. Maximal rhematic focus obtains when a DP is deeply embedded within the predicate domain. It is not unreasonable to assume that whenever there is need to focus/emphasize the object, a null expletive pro, available to the mental lexicon of these dialects as already discussed, is merged in the specifier of $\operatorname{Tr}$ (the proxy head of $\mathrm{v}^{*}$ ) to satisfy [uD], thus preventing the object from displacement. This would ensure an "inverted-object" construction similar to the inverted subject constructions of Romance which have been argued by Rizzi (1997), among others, to involve rhematic focusing of the subject. Maximal embedding of the object yields the desired pragmatic effects, while at the same time guaranteeing NOM, as shown in (55):

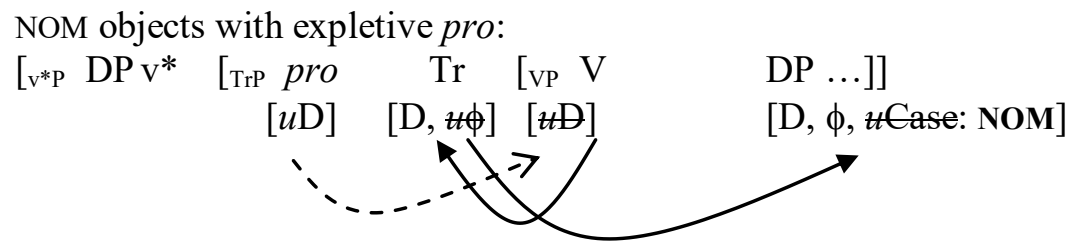

These data all point to a dissociation between specific syntactic heads and particular Case values and strengthen the exclusive relationship between NOM valuation and the presence of $\phi$-features.

\footnotetext{
${ }^{58}$ Khoekhoe lacks agreement morphology, RCT stands for 'recent' past and ! ${ }^{\mathrm{x}}$ denotes an alveolar click with a velar fricative manner/release (Richard Compton, personal communication).
} 


\section{General Implications for Case}

Following insights in Vergnaud's (1977) seminal work, Chomsky (1980) proposes the Case Filter, initially viewed as a PF requirement given its focus on lexical NPs (and later A-chains). However, since wh-phrases have Case, Chomsky (1981) revises the Case Filter to include variables and, with the PF motivation gone, capitalizes on work by Aoun (1979) suggesting instead that the Case Filter is motivated by LF, with Case rendering an argument visible for theta-role assignment. Lasnik (2008) revisits this split and, based on facts from ellipsis (a PF process) - which "repairs" otherwise ungrammatical data, see (56) - concludes that "the Case Filter is, in fact, a PF requirement" (Lasnik 2008: 35).

$$
\begin{aligned}
& \text { a. } \quad \text { I alleged John to be a fool. } \\
& \text { b. John, I alleged to be a fool. } \\
& \text { c Mary did [allege John to be a fool] too. }
\end{aligned}
$$

Specifically, while (56a) is ungrammatical since John fails to receive Case, (56b-c) are well-formed. In (56b), A-bar movement satisfies the Case Filter (following Kayne 1984 and Bošković 1997), while in (56c) deletion, a PF process, must be responsible for repairing the violation in (56a). Since a PF process can fix this violation, it must have necessarily been a PF problem to begin with.

Lasnik's (2008) conclusion is in line with work by Sigurðsson $(2008,2009)$ arguing for Case as a PF morphology property, with no LF or syntactic counterpart, but runs counter to proposals where Case is still assumed to be structurally relevant (Legate 2008). Furthermore, Lasnik's (2008: 35) final comment as to "what it means for items with no phonetic content (PRO, $\mathrm{WH}$-trace) to have to obey a PF requirement" is left for future consideration.

The analysis in this paper supports Lasnik's (2008) view while also maintaining the syntactic relevance of Case. Since the NOM versus ACC split is argued to be dependent on the presence versus absence of $[u \phi / \pi]$, respectively, Case valuation is syntactically determined. The presence of [uCase] as a deficiency on nominal arguments is postulated for visibility requirements within the computational system. Returning to Lasnik's last comment, [uCase] is then irrelevant for null arguments like PRO or pro, as there is no lexical insertion. But the crucial point is that syntax is not privy to this irrelevancy as the computational component cannot tell whether something will be subsequently lexicalized or not (i.e. is null or not). On the other hand, for non-argument DPs, which lack [uCase], Case valuation cannot obtain. Nonetheless, PF has to insert a vocabulary item, so will insert the language default form (à la Schütze 2001). A schematic representation is offered in (57):

(i) $\mathrm{DP}_{\theta}[\mathrm{uCase}]$ :

$>$ inherent Case or A-Probed (lexical DP, referential pro, PRO)

$\rightarrow$ specific valuation instructions sent to $\mathrm{PF}$

$\checkmark$ DP [uCase: $\mathrm{K}_{1} / \mathrm{K}_{2} / \ldots / \mathrm{K}_{\mathbf{n}}$ ] 


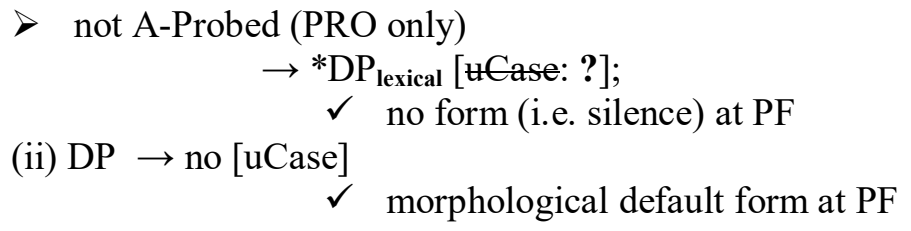

\section{Conclusions}

This paper is an attempt at refining our understanding of Case licensing and valuation in view of Minimalist advances and DM models. It distinguishes between syntactic/abstract Case, construed as a [uCase] feature on DP arguments for computational visibility purposes, and morphological Case, seen as equivalent to DP lexicalization forms. It assumes that [uCase] is synonymous to the Case Filter and is driven by PF rather than LF considerations.

Case licensing, understood as checking of [uCase], is shown to be a property of phase heads (i.e. points of Transfer) and not of agreement (or tense, or default options). Valuation as NOM or ACC is argued to be a dynamic property of the entire probing domain, rather than being associated with finite $\mathrm{T}$ and phasal $\mathrm{v}$, respectively. Non-finite domains, while lacking agreement, are cross-linguistically seen to license both NOM and ACC lexical subjects, while certain predicate domains may license NOM objects. Probing domains that are phi-complete (crucially containing $\pi$ ) associate with NOM values, while simple $[\mathrm{uD}]$ A-Probes trigger ACC. While this account departs from standard assumptions correlating structural Case with agreement, it does maintain a dichotomy in which agreement is the crucial ingredient.

In the absence of $\phi$-features on $(\mathrm{C})-\mathrm{T}$, the Probe is either a $[\mathrm{uD}]$ deficiency or a null expletive. Null expletives are argued to be felicitous primitives of Universal Grammar with a role in NOM Case valuation. Their presence in the derivation is parametrized and strictly semantico-pragmatically determined, as discussed.

NOM, then, is not a primitive of finite or inflected $\mathrm{T}$ but the spell-out of a bundle of features, conspicuously available to phasal domains as long as the $\phi$-specification is met. Overall T (or I, more generally) is typically associated with NOM, and $\mathrm{v}^{*}$ with ACC, because the issue of finiteness and, implicitly, the presence of a $[u \phi]$ Probe on an inflectional head is sorted out at the level of the $\mathrm{C}$ phase and not the $\mathrm{v}^{*}$ phase.

The analysis proposed here, based on feature-al specifications of probing domains, allows for the flexibility needed to capture cross-linguistic variation at both the macroand micro-parametric levels, while at the same time having the conceptual merit of moving the burden of Case values away from some poorly understood independent property of $(\mathrm{C})-\mathrm{T}$ and $\mathrm{v}^{*}$.

\section{References}

Abels, K. 2003. Successive Cyclicity, Anti-locality, and Adposition Stranding. PhD dissertation, University of Connecticut, Storrs.

Abney, S. Paul. 1987. The English Noun Phrase in its Sentential Aspect. PhD dissertation, MIT, Cambridge. 
Adger, D. 2003. Core Syntax: A Minimalist Approach. Oxford: Oxford University Press.

Adger, D. 2007. Three domains of finiteness: A minimalist perspective. In I. Nikolaeva (ed.), Finiteness: Theoretical and Empirical Foundations, 23-59. Oxford: Oxford University Press.

Al-Balushi, R. 2011. Case in Standard Arabic: The Untravelled Paths. PhD dissertation, University of Toronto, Toronto.

Alboiu, G. 1999. (De)-Focusing and Object Raising in Romanian. Canadian Journal of Linguistics 44: 1-22.

Alboiu, G. 2002. The Features of Movement in Romanian. Bucharest: Editura Universităţii București.

Alboiu, G. 2006. Are we in Agreement? In C. Boeckx (ed.), Agreement Systems, 13-39. Amsterdam/ Philadelphia: John Benjamins.

Alboiu, G. 2007. Moving Forward with Romanian Backward Control and Raising. In W. D. Davies and S. Dubinsky (eds.), New Horizons in the Analysis of Control and Raising, 187-213. Dordrecht: Springer.

Alboiu, G. 2009. Null expletives and Case: The view from Romance. In P. J. Masullo, E. O'Rourke and C.-H. Huang (eds.), Romance Linguistics 2007, 1-19. Amsterdam/Philadelphia: John Benjamins.

Alboiu, G. and Avery, P. 2009. Argument-Adjunct asymmetries in Ndebele: The long and the short of it. Bucharest Working Papers in Linguistics XI (1): 165-187.

Alboiu, G, Hill, V. and Sitaridou, I. 2015. Discourse driven V-to-C in Early Modern Romanian. Natural Language and Linguistic Theory 33 (4): 1057-1088.

Alexiadou, A. and Anagnastopoulou, E. 1998. Parametrizing AGR: Word Order, V-Movement and EPP-checking. Natural Language and Linguistic Theory 16: 491-539.

Ambar, M. 2006. Verb movement and Tense: EPP and t-completeness. In M. C. Picchi and A. Pona (eds.), 1-20. Proceedings of the XXII Incontro di Grammatica Generativa, 1-20. Alessandria: Edizioni dell'Orso.

Aoun, J. 1979. On government, Case-marking, and clitic placement. Ms., MIT.

Avram, L. 2003. An aspectual analysis of gerunds. Revue roumaine de linguistique XLVIII (1): 203-219.

Baker, M. C. 1996. The Polysynthesis Parameter. Oxford: Oxford University Press.

Baker, M. C. 2008. The Syntax of Agreement and Concord. Cambridge: Cambridge University Press.

Baker, M. C. 2015. Case: Its Principles and its parameters. Cambridge: Cambridge University Press.

Baker, M. C., Aranovich, R. and Golluscio, L. A. 2005. Two types of syntactic noun incorporation: Noun incorporation in Mapudungun and its typological implications. Language 81: 138-177.

Baltin, M. 1995. Floating quantifiers, PRO, and predication. Linguistic Inquiry 26: 199-248.

Baltin, M. and Barrett, L. 2002. The Null Content of Null Case. Ms., New York University. http://linguistics. as.nyu.edu/object/MarkRBaltin.html.

Bartos, H. 1997. On "subjective" and "objective" agreement in Hungarian. Acta Linguistica Hungarica 44: 363-384.

Băncila, F. 1991. The Historical Evolution of the Impersonal Sentence Structure in English. Bucharest: Tipografia Universităţii Bucureşti.

Belletti, A. 1990. Generalized Verb Movement. Torino: Rosenberg and Sellier.

Bianchi, V. 2008. Person and the left periphery. Ms, University of Siena.

Binnick, R. 1991. Time and the Verb. Oxford: Oxford University Press.

Bittner, M. and Hale, M. 1996. Ergativity: Towards a theory of a heterogeneous class. In Linguistic Inquiry 27: 531-604

Bobaljik, J. D. and Landau, I. 2009. Icelandic control is not A-movement: The case from case. Linguistic Inquiry 40: 113-132.

Boeckx, C. and Hornstein, N. 2006. Control in Icelandic and theories of control. Linguistic Inquiry 37: 591-607.

Bošković, Z. 1997. The Syntax of Nonfinite Complementation: An Economy Approach. Cambridge, MA: MIT Press.

Bošković, Z. 2006. Case and Agreement with Genitive of quantification in Russian. In C. Boeckxs (ed.), Agreement Systems, 99-121. Amsterdam/Philadelphia: John Benjamins

Bowers, J. 2002. Transitivity. Linguistic Inquiry 33: 183-225.

Branigan, P. 2005. Case Valuation by Phase. Ms., Memorial University.

Cardinaletti, A. 1997. Agreement and control in expletive constructions. Linguistic Inquiry 28: 521-534.

Cardinaletti, A. 2004. Toward a cartography of subject positions. In L. Rizzi (ed.), The Structure of CP and IP: The Cartography of Syntactic Structures, vol. 2, 115-166. Oxford: Oxford University Press.

Carstens, V. 2001. Multiple agreement and case deletion: Against $\phi$-(in)completeness. Syntax 4: 147-163.

Cecchetto, C. and Oniga, R. 2004. A challenge to Null Case Theory. Linguistic Inquiry 35: 141-149. 
Chierchia, G. 1989. Anaphora and attitudes de se. In R. Bartsch, J. van Benthem and P. van Emde Boas (eds.), Semantics and Contextual Expression, 1-32. Dordrecht: Foris.

Chomsky, N. 1980. On Binding. Linguistic Inquiry: 1-46.

Chomsky, N. 1981. Lectures on Government and Binding. Dordrecht: Foris.

Chomsky, N. 1982. Some Concepts and Consequences of the Theory of Binding. Cambridge, MA: The MIT Press.

Chomsky, N. 1986. Barriers. Cambridge, MA: MIT Press.

Chomsky, N. 1995. The Minimalist Program. Cambridge, MA: MIT Press.

Chomsky, N. 2000. Minimalist inquiries: The framework. In R. Martin, D. Michaels and J. Uriagereka (eds.), Step by Step: Essays on Minimalist Syntax in Honor of Howard Lasnik, 89-147. Cambridge, MA: The MIT Press.

Chomsky, N. 2001. Derivation by Phase. In M. Kenstowicz (ed.), Ken Hale: A Life in Language, 1-52. Cambridge, MA: The MIT Press.

Chomsky, N. 2004. Beyond Explanatory Adequacy. In A. Belletti (ed.), Structures and Beyond: The Cartography of Syntactic Structures, vol. 3, 104-132. Oxford: Oxford University Press.

Chomsky, N. 2007. Approaching UG from below. In U. Sauerland and H.-M. Gartner (eds.), Interfaces + Recursion = Language?: Chomsky's Minimalism and the View from Syntax-Semantics, 1-29. Berlin · New York: Mouton de Gruyter.

Chomsky, N. 2008. On Phases. In R. Freidin, C. P. Otero and M. L. Zubizarreta (eds.), Foundational Issues in Linguistic Theory: Essays in Honor of Jean-Roget Vergnaud, 133-167, Cambridge, MA: The MIT Press.

Chomsky, N. and Lasnik, H. 1995. The Theory of Principles and Parameters. In N. Chomsky, The Minimalist Program, 13-129. Cambridge, MA: The MIT Press.

Chung, S. and McCloskey, J. 1987. Government, barriers and small clauses in Modern Irish. Linguistic Inquiry 18: 173-237.

Cinque, G. 1990. Types of A-bar Dependencies. Cambridge, MA: The MIT Press.

Cole, P. and Jake, J. L. 1978. Accusative subjects in Imbabura Quechua. Studies in the Linguistic Sciences 8: $72-96$.

Coppock, E. 2004. Object agreement in Hungarian. Paper presented at LFG 2004, Christchurch, New Zealand. http://www.mendeley.com/profiles/elizabeth-coppock.

Cornilescu, A. 1997. The double subject construction. Notes on the syntax of the subject. Revue roumaine de linguistique XLII (3-4): 101-147.

Cornilescu, A. 2000a. Notes on the interpretation of the prepositional accusative in Romanian. Bucharest Working Papers in Linguistics II (1): 91-107.

Cornilescu, A. 2000b. The double subject construction in Romanian. In V. Motapanyane (ed.), Comparative Studies in Romanian Syntax, 83-134. Dordrecht: Elsevier.

Cornilescu, A. 2003. Complementation in English. Bucharest: Editura Universității din București.

Cowper, E. 1995. English participial constructions. Canadian Journal of Linguistics 40: 1-38.

Cowper, E. and Hall, D. C. 2001. Overriding the Phase. In Proceedings of the Annual Conference of the Canadian Linguistic Association, 13-23. Ottawa: Cahiers Linguistiques d'Ottawa.

Culicover, P. 1999. Syntactic Nuts: Hard Cases, Syntactic Theory and Language Acquisition. Oxford: Oxford University Press.

Diesing, M. 1992. Indefinites. Cambridge, MA: The MIT Press.

Dobrovie-Sorin, C. 1994. The Syntax of Romanian: Comparative Studies in Romance. Berlin: Mouton de Gruyter.

Embick, D. 2007. Blocking effects and analytic/synthetic alternations. Natural Language and Linguistic Theory 25: 1-37.

Emonds, J. 1970. Root and Structure Preserving Transformations. PhD dissertation, MIT, Cambridge.

Farkas, D. 1992. On the semantics of subjunctive complements. In P. Hirschbuhler (ed.), Papers from the 20th Linguistic Symposium on Romance Languages, 69-105. Amsterdam/Philadelphia: John Benjamins.

Fischer, O., van Kemenade, A., Koopman, W. and van der Wurff, W. 2000. The Syntax of Early English. Cambridge: Cambridge University Press.

Freidin, R. and Sprouse, R. A. 1991. Lexical case phenomena. In R. Freidin (ed.), Principles and Parameters in Comparative Grammar, 392-416. Cambridge, MA: The MIT Press. 
George, L. and Kornfilt, J. 1981. Finiteness and boundedness in Turkish. In F. Heny (ed.), Binding and Filtering, 105-127. Cambridge, MA: MIT Press.

Giorgi, A. and Pianesi, F. 1997. Tense and Aspect: From Semantics to Morphosyntax. Oxford: Oxford University Press.

Haeberli, E. 2002. Features, Categories and the Syntax of A-Positions: Cross-Linguistic Variation in the Germanic Languages. Dordrecht: Kluwer Academic Publishers.

Haider, H. 1988. Matching projections. In A. Cardinaletti, G. Cinque and G. Giusti (eds.), Constituent Structure: Papers from the 1987 GLOW Conference, 101-123. Annali di Ca' Foscari XXXVII (4).

Halle, M. and Marantz, A. 1993. Distributed Morphology and the pieces of inflection. In K. Hale and S. J. Keyser (eds.), The View from Building 20: Essays in Linguistic in Honor of Sylvain Bromberger, 111-176. Cambridge, MA: MIT Press.

Harley, H. 1995. Subjects, Events, and Licensing. PhD dissertation, MIT, Cambridge.

Haegeman, L. 1985. INFL, COMP and Nominative Case assignment in Flemish infinitivals. In P. Muysken and H. van Riemsdijk (eds.), Features and Projections, 123-137. Dordrecht: Kluwer Academic Publishers.

Henry, A. 1995. Belfast English and Standard English: Dialect Variation and Parameter Setting. Oxford: Oxford University Press.

Hill, V. and Alboiu, G. 2016. Verb Movement and Clause Structure in Old Romanian. Oxford: Oxford University Press.

de Hoop, H. 1996. Case Configuration and Noun Phrase Interpretation. New York : Garland Publishing.

Horn, G. 1975. On the nonsentential nature of the POSS-ing constructions. Linguistic Analysis 1: 333-338.

Hornstein, N. 1999. Movement and control. Linguistic Inquiry 30: 69-96.

Thalainen, O. 1991. The grammatical subject in educated and dialectal English: Comparing the London-Lund Corpus and the Helsinki Corpus of Modern English Dialects. In S. Johansson and A.-B. Stenstrøm (eds.), English Computer Corpora. Selected Papers and Research Guide, 201-214. Berlin and New York: Mouton.

Irimia, M. 2009. Topics in Secondary Predicates. PhD dissertation, University of Toronto.

Jespersen, O. 1924. The Philosophy of Grammar. London: Allen and Unwin.

Jespersen, O. 1940/1961. A Modern English Grammar. London: Allen and Unwin., Copenhagen: Munsgaard.

Kaulen, F. 1904. Sprachliches Handbuch zur biblischen Vulgata: Eine systematische Darstellung ihres lateinischen Sprachcharakters. Freiburg im Breisgau: Herder.

Kayne, R. 1984. Connectedness and Binary Branching. Dordrecht: Foris.

Kayne, R. 1991. Romance clitics, verb movement and PRO. Linguistic Inquiry 22: 647-686.

Kayne, R. 2008. Expletives, datives, and the tension between morphology and syntax. In T. Biberauer (ed.), The Limits of Syntactic Variation, 175-217. Amsterdam/Philadelphia: John Benjamins.

Kenesei, I. 1986. On the role of the agreement morpheme in Hungarian. Acta Linguistica Academiae Scientiarum Hungaricae 36: 109-120.

Kramer, R. 2010. Object markers in Amharic. Paper presented at the $41^{\text {st }}$ Annual Conference on African Linguistics. The University of Toronto and York University, May 6-8 2010, Toronto.

Krapova, Y. 2001. Subjunctives in Bulgarian and Modern Greek. In M. L. Rivero and A. Ralli (eds.), Comparative Syntax of Balkan Languages, 105-127. Oxford: Oxford University Press.

Kratzer, A. 2009. Making a pronoun: Fake indexicals as windows into the properties of pronouns. Linguistic Inquiry 40: 187-239.

Landau, I. 1999. Elements of Control. Doctoral dissertation, MIT, Cambridge.

Landau, I. 2001. Control and extraposition: The case from Super-Equi. Natural Language and Linguistic Theory 19: 109-152.

Landau, I. 2003. Movement out of control. Linguistic Inquiry 34: 471-499.

Landau, I. 2004. The scale of finiteness and the calculus of control. Natural Language and Linguistic Theory 22: 811-877.

Landau, I. 2008. Two routes of control: Evidence from case Transmission in russian. Natural Language and Linguistic Theory 26: 877-924.

Landau, I. 2013. Control in Generative Grammar: A Research Companion. Cambridge: Cambridge University Press.

Lasnik, H. 1999. Minimalist Analysis. Malden, MA and Oxford: Blackwell.

Lasnik, H. 2003. Minimalist Investigations in Linguistic Theory. London and New York: Routledge. 
Lasnik, H. 2008. On the development of Case Theory. In R. Freidin, C. P. Otero and M. L. Zubizarreta (eds.), Foundational Issues in Linguistic Theory: Essays in Honor of Jean-Roget Vergnaud, 133-167, Cambridge, MA: The MIT Press.

Ledgeway, A. 1998. Variation in the Romance infinitive: The case of the Southern Calabrian inflected infinitive. Transactions of the Philological Society 96: 1-61.

Legate, J. A. 1999. The morphosyntax of Irish agreement. In K. Arregi, B. Bruening, C. Krause and V. Lin (eds.), Papers on Morphology and Syntax, Cycle One, 1-21. MIT Working Papers in Linguistics 33.

Legate, J. A. 2008. Morphological and abstract case. Linguistic Inquiry 39: 55-103.

Manzini, R. M. and Roussou, A. 2000. A minimalist theory of A-movement and control. Lingua 110 (6) : 409-447.

Manzini, R. M. and Savoia, L. M. 1997. Null subjects without pro. In UCL Working Papers in Linguistics $9: 303-313$.

Manzini, R. M. and Savoia, L. M. 2002. Parameters of subject inflection in Italian dialects. In P. Svenonius (ed.), Subjects, Expletives and the EPP, 157-200. Oxford: Oxford University Press.

Manzini, R. M. and Savoia, L. M. 2008. Uninterpretable features are incompatible in morphology with other minimalist postulates. In R. Freidin, C. P. Otero and M. L. Zubizarreta (eds.), Foundational Issues in Linguistic Theory: Essays in Honor of Jean-Roger Vergnaud, 43-73. Cambridge, MA: The MIT Press.

Marantz, A. 2000. Case and licensing. In E. Reuland (ed.), Arguments and Case: Explaining Burzio's Generalization, 11-30. Amsterdam/Philadelphia: John Benjamins.

Marantz, A. 2001. Words. Paper presented at $20^{\text {th }}$ West Coast Conference on Formal Linguistics, 23-25 February 2001, University of Califonia at Santa Cruz.

Markman, V. G. 2009. On the parametric variation of case and agreement. Natural Language and Linguistic Theory 27: 379-426.

Martin, R. 2001. Null case and the distribution of PRO. Linguistic Inquiry 32: 141-166.

Mensching, G. 2000. Infinitive Constructions with Specified Subjects: A Syntactic Analysis of the Romance Languages. Oxford: Oxford University Press.

McCawley, J. D. 1988. The Syntactic Phenomena of English. Chicago and London: The University of Chigaco Press.

McCloskey, J. 1985. Case, movement and raising in Modern Irish. In J. Goldberg, S. MacKaye and M. Wescoat (eds.), Proceedings of the Fourth West Coast Conference on Formal Linguistics, 190-205. Stanford, CA: CSLI Publications.

Miyagawa, S. 2010. Why Agree? Why Move? Unifying Agreement-based and Discourse Configurational Languages. Cambridge, MA The MIT Press.

Miyagawa, S. 2017. Agreement Beyond Phi. Cambridge, MA: The MIT Press.

Motapanyane, V. 1995. Theoretical Implications of Complementation in Romanian. Padova: Unipress.

Motapanyane, V. 2000. Parameters for focus in English and Romanian. In V. Motapanyane (ed.), Comparative Studies in Romanian Syntax, Dordrecht: Elsevier.

Moulton, K. 2004. External arguments and gerunds. Toronto Working Papers in Linguistics 22: 121-136.

Oda, K. 2002. Wh-questions in a V-initial language. Ms, University of Toronto.

Pesetsky, D. and Torrego, E. 2001. T-to-C Movement : Causes and consequences. In M. Kenstowicz (ed.), Ken Hale: A Life in Language, 355-426. Cambridge, MA: The MIT Press.

Pesetsky, D. and Torrego, E. 2004a. Tense, case, and the nature of syntactic categories. In J. Gueron and J. Lacarme (ed.), 495-539. Cambridge, MA: The MIT Press.

Pesetsky, D. and Torrego, E. 2004b. The syntax of valuation and the interpretability of features. Ms., MIT.

Pesesky, D. and Torrego, E. 2006. Probes, goals and syntactic categories. In Y. Otsu (ed.), Proceedings of the Seventh Tokyo Conference on Psycholinguistics, 25-61. Tokyo : Hituzi Syobo.

Pires, A. 2001. The Syntax of Gerunds and Infinitives: Subjects, Case, and Control. PhD dissertation, University of Maryland, College Park.

Pires, A. 2006. The Minimalist Syntax of Defective Domains: Gerunds and Infinitives. Amsterdam/ Philadelphia: John Benjamins.

Pires, A. 2007. The derivation of clausal gerunds. Syntax 10 (2): 165-203.

Poletto, C. 2000. The Higher Functional Head: Evidence from Northern Italian Dialects. New York and Oxford: Oxford University Press.

Portner, P. 1992. Situation Theory and the Semantics of Propositional Expressions. PhD dissertation, University of Massachusetts, Amherst. 
Poutsma, H. 1929. A Grammar of Late Modern English, second edition. Groningen: P. Noordhoff.

Pylkännen, L. 2008. Introducing Arguments. Cambridge, MA: The MIT Press.

Raposo, E. 1987. Case Theory and Infl-to-Comp: The inflected infinitive in European Portuguese. Linguistic Inquiry 18: 85-109.

Raposo, E. 1989. Prepositional infinitival constructions in European Portuguese. In O. Jaeggli and K. J. Safir (eds.), The Null Subject Parameter, 277-305. Dordrecht: Kluwer Academic Publishers.

Reed, L. A. 2011. Modifying and strengthening the PRO hypothesis. Abstract for Ling-Lunch presentation, MIT, March 10

Reichenbach, H. 1947. Elements of Symbolic Logic. New York: The Free Press.

Reuland, E. J. 1983. Governing -ing. Linguistic Inquiry 14: 101-136.

Rezac, M. 2004. Elements of Cyclic Syntax: Agree and Merge. PhD dissertation, University of Toronto.

Rezac, M. 2010. f-Agree versus f-Feature Movement: Evidence from floating quantifiers. Linguistic Inquiry 41: 496-509.

Rice, K.1989. A Grammar of Slave. Berlin: Mouton de Gruyter.

Richards M. D. 2007. On Feature Inheritance: An argument from the Phase Impenetrability Condition. Linguistic Inquiry 38: 439-492.

Richardson, K. 2007. Case and Aspect in Slavic. Oxford: Oxford University Press.

Rizzi, L. 1982. Issues in Italian Syntax. Dordrecht: Foris.

Rizzi, L. 1997. The fine structure of the Left Periphery. In L. Haegemann (ed.), Elements of Grammar, 281-337. Dordrecht: Kluwer Academic Publishers.

Rizzi, L. 2004. On the cartography of syntactic structures. In L. Rizzi (ed.), The Structure of CP and IP: The Cartography of Syntactic Structures, vol. 2, 3-16. Oxford: Oxford University Press.

Rizzi, L. and Shlonski, U. 2005. Strategies of subject extraction. Ms., University of Siena and University of Geneva.

Roberts, I. 1993. Verbs and Diachronic Syntax: A Comparative Study of English and French. Dordrecht: Kluwer Academic Publishers.

Roberts, I. 2010. Agreement and Head Movement: Clitics, Incorporation, and Defective Goals. Cambridge: The MIT Press.

Roberts, I. and Roussou, A. 2002. The Extended Projection Principle as a condition on the tense-dependency. In P. Svenonius (ed.), Subjects, Expletives and the EPP, 125-157. Oxford: Oxford University Press.

Roussou, A. 2006. Subjects on the edge. Paper presented at the "Edges in Syntax" Conference, Cyprus College.

Săvescu-Ciucivara, Oana. 2007. Challenging the Person Case Constraint: Evidence from Romanian. Paper presented at the 36th Linguistic Symposium on Romance Languages (LSRL), 15-18 March, Pittsburgh.

Schütze, C. T. 1997. INFL in Child and Adult Language. PhD dissertation. MIT, Cambridge, Mass.

Schütze, C. T. 2001. On the nature of default Case. Syntax 4 (3): 205-238.

Schwendener, U. 1923. Der accusativus cum infinitivo im Italienischen. PhD dissertation, Universität Bern.

Sevdali, C. 2005. Tense and Ancient Greek infinitives. In M. Coene and L. Tasmovski (eds.), On Space and Time in Language, 129-150. Cluj-Napoca: Clusium.

Sevdali, C. 2007. Infinitival Clauses in Ancient Greek: Overt and Null Subjects, the Role of Case and Focus. $\mathrm{PhD}$ dissertation, Cambridge University.

Sigurðsson, H. 1991. Icelandic case-marked PRO and the licensing of lexical arguments. Natural Language and Linguistic Theory 9: 327-364.

Sigurðsson, H. Á. 2008. The case of PRO. Natural Language and Linguistic Theory 26: 403-450.

Sigurðsson, H. Á. 2009. The No Case Generalization. In A. Alexiadou, J. Hankamer, T. McFadden, J. Nuger and F. Schäfer (eds.), Advances in Comparative Germanic Syntax, 249-279. Amsterdam/Philadelphia: John Benjamins.

Sitaridou, I. 2002. The Synchrony and Diachrony of Romance Infinitives with Nominative Subjects. PhD dissertation, University of Manchester.

Stowell, T. 1982. The tense of infinitives. Linguistic Inquiry 13: 561-570.

Svenonius, P. 2001. Case and Event Structure. In N. Zhang (ed.), ZAS Papers in Linguistics 26: 197-218.

Svenonius, P. 2004. On the edge. In D. Adger, C. de Cat and G. Tsoulas (eds.), Peripheries: Syntactic Edges and their Effects, 259-287. Dordrecht: Kluwer Academic Publishers.

Szabolcsi, A. 1983. The possessor that ran away from home. The Linguistic Review 3: 89-102. 
Szabolcsi, A. 2007. Hidden in plain sight: Overt subjects in infinitival control and raising complements. http://ling.auf.net/linBuzz/000445.

Tomić, O. M. 2006. Balkan Sprachbund Morphosyntactic Features. Dordrecht: Springer.

Torrego, E. 1998. Nominative subjects and Pro-Drop INFL. Syntax 1: 206-219.

Ura, H. 2000. Checking Theory and Grammatical Functions in Universal Grammar. Oxford: Oxford University Press.

Uriagereka, J. 1995. Aspects of the syntax of clitic placement in Western Romance. Linguistic Inquiry 26: $79-123$.

Uriagereka, J. 2002. Derivations: Exploring the Dynamics of Syntax. New York: Routledge.

Uriagereka, J. 2006. Complete and partial Infl. In C. Boeckxs (ed.), Agreement Systems, 267-299. Amsterdam/Philadelphia: John Benjamins.

Uriagereka, J. 2008. Syntactic Anchors. Cambridge: Cambridge University Press.

Varlokosta, S. 1994. Issues in Modern Greek Sentential Complementation. PhD dissertation, Univ. of Maryland.

Vergnaud, J.-R. 1977/2008. Letter to Noam Chomsky and Howard Lasnik on "Filters and Control", April 17, 1977. In R. Freidin, C. P. Otero and M. L. Zubizarreta (eds.), Foundational Issues in Linguistic Theory: Essays in Honor of Jean-Roger Vergnaud, 3-17. Cambridge, MA: The MIT Press.

Watanabe, A. 1996. Case Absorption and WH-Agreement. Dordrecht: Kluwer Academic Publishers

Woolford, E. 1997. Four-way case systems: Ergative, nominative, objective, and accusative. Natural Language and Linguistic Theory 15: 181-227.

Woolford, E. 2003. Clitics and agreement in competition: Ergative cross-referencing patterns. In A. Carpenter, A. Coetzee and P. de Lacy (eds.), Papers in Optimality Theory II, 421-449. Amherst, MA: Graduate Linguistics Student Association.

Woolford, E. 2006. Lexical case, inherent case, and argument structure. Linguistic Inquiry 37 (1): 111-130.

Wyngaerd, G. J. Vanden. 1994. PRO-legomena: Distribution and Reference of Infinitival Subjects. Berlin and New York: Mouton de Gruyter.

Zubizarreta, M. 1998. Prosody, Focus and Word Order. Cambridge, MA: The MIT Press. 
